\title{
Isotopic composition of lead in volcanic rocks from central Honshu - with regard to basalt genesis*
}

\author{
Mitsunobu TAtSumoto and RoY J. KNIGHT \\ U. S. Geological Survey \\ Denver, Colorado 80225, U.S.A.
}

(Received June 10, 1969)

\begin{abstract}
The isotopic composition of lead and concentrations of lead, uranium, and thorium were determined in tholeiitic and high-alumina basalts, and their calc-alkali rock series, from central Japan.

The isotopic composition of lead of high-alumina basalts is similar to that of tholeiites from adjacent areas, whereas their silicic differentiates (calc-alkali rock series) are rich in ${ }^{207} \mathrm{~Pb}$ and ${ }^{208} \mathrm{~Pb}$. This is interpreted as a result of crustal contamination. The isotopic composition of lead in the primary basalts gradually decreases in radiogenic character from the Pacific Ocean side to the Japan Sea side, whereas the observed ${ }^{238} \mathrm{U} /{ }^{204} \mathrm{~Pb}$ and ${ }^{232} \mathrm{Th} /{ }^{238} \mathrm{U}$ ratios in the basalts increase in the same direction. This inverse correlation can be interpreted as resulting from differentiation of the upper mantle about 3.6b.y. ago, with tholeiite (Pacific side) generated from a shallower zone than the alkali basalt (Japan Sea side). The magma generation is associated with a process which extracts $\mathrm{Pb}$ preferentially to $\mathrm{U}$ and $\mathrm{Th}$ at shallower depth and $\mathrm{U}$ and $\mathrm{Th}$ preferentially to $\mathrm{Pb}$ at deeper depth in the past (multi differentiation for the source region) or at the magma generation stage. An alternative interpretation of this inverse correlation is that the ocean floor is being thrust under the Japanese Island arcs and the isotopic difference is produced by the degree of mixing of mantle material under the arcs with thrust material.
\end{abstract}

\section{INTRODUCTION}

Lead has four stable isotopes, ${ }^{204} \mathrm{~Pb},{ }^{206} \mathrm{~Pb},{ }^{207} \mathrm{~Pb}$ and ${ }^{208} \mathrm{~Pb} .{ }^{204} \mathrm{~Pb}$ has no longlived parent, but ${ }^{206} \mathrm{~Pb},{ }^{207} \mathrm{~Pb}$ and ${ }^{208} \mathrm{~Pb}$ are final decay products of ${ }^{238} \mathrm{U},{ }^{235} \mathrm{U}$ and ${ }^{232} \mathrm{Th}$, respectively; therefore, the isotopic composition of lead in a given chemical system is controlled by the initial lead inherited in the system plus the time-integrated result of uranium-thorium-lead ratios. Thus the relative abundance of lead isotopes and of lead, uranium and thorium in basalts provides information on the differentiation history of source material and/or the genetic relationship of basalts. Comagmatic rocks should have identical lead isotopic compositions when they crystallized, if variable contamination with extraneous lead is negligible. Different isotopic compositions

* Publication authorized by the Director, U. S. Geological Survey 
indicate that the rocks either are not comagmatic or are comagmatic but contaminated.

Lead isotopes in Japanese volcanic rocks have been reported by MASUDA (1964), TATSumoto (1966a), and CoOPER and Richards (1966). To extend the previous work we planned an extensive study of isotope tracer work on tholeiites, high-alumina basalts and alkali basalts of Japan as a part of the U.S.-Japan Science Cooperation Program. This report is concerned with tholeiites and high-alumina basalts from central Japan. Related studies on alkali basalt series of Oki-dogo island and on volcanic rocks from northern part of Japan are reported by KURASAWA (1968) and by HEDGE and KNIGHT (1969) respectively.

The results of the present study are in agreement with the previous conclusion of ТАтsUмото (1966a) that isotopic variations of lead in the Japanese volcanic rocks are due to different source materials in a heterogeneous upper mantle, with alkali basalts generated from a deeper source than tholeiites. However, the present data also suggest the possibility of an alternative interpretation, involving ocean-floor thrusting under the Japanese Island arcs.

\section{Geologic Setting of Samples}

The Japanese Islands are situated at the margin of the Eurasian Continent and constitute a part of the circum-Pacific orogenic zone. The island arc was built on a lower Paleozoic or Precambrian(?) crystalline basement by deposition of a Phanerozoic geosynclinal pile and by volcanism (GoRAI, 1968; Rikitake et al., 1968). This geosynclinal pile has undergone repeated regional metamorphism. In central and west Japan two pairs (low and high $P / T$ type; MIYASHIRO, 1967) of metamorphic belts were produced. The older pair of metamorphic belts (Japan Sea side) appears to have formed in late Paleozoic to Triassic but the younger pair (Pacific Ocean side) probably in Mesozoic time (rocks from Ryoke-Abukuma metamorphic belt are about $100 \mathrm{~m} . \mathrm{y}$. old; UENO et al., 1968). Recent studies of phase velocity, of Rayleigh waves (AKI, 1961; KAMINUMA and AKI, 1963; KAMINUMA, 1964) indicate that the thickness of the crust is about the same for O-shima-Izu area and Oki-dogo area (about $30 \mathrm{~km}$ ), but slightly thicker for the middle part of central Honshu.

Kuno $(1959,1960,1967)$ divided the Japanese Islands into three petrologic provinces by the nature of the Quaternary basalts (Fig.1). Tholeiite* series occur in a zone close to the Pacific Ocean side of the islands and extend to the Izu and Mariana Islands. An alkali province includes the Japan Sea side of the islands and extends to Korea, Manchuria, and Sakhalin. The high-alumina basalt series occur in an intermediate zone between the tholeiitic and alkali rock provinces. Within the three petrographic provinces there are calc-alkali rock series which appear to have been

* Terms of rock types in this paper follow those used by KUNO $(1959,1968)$, and the term 'calc-alkali' rock series is used only for the hypersthenic rock series. 


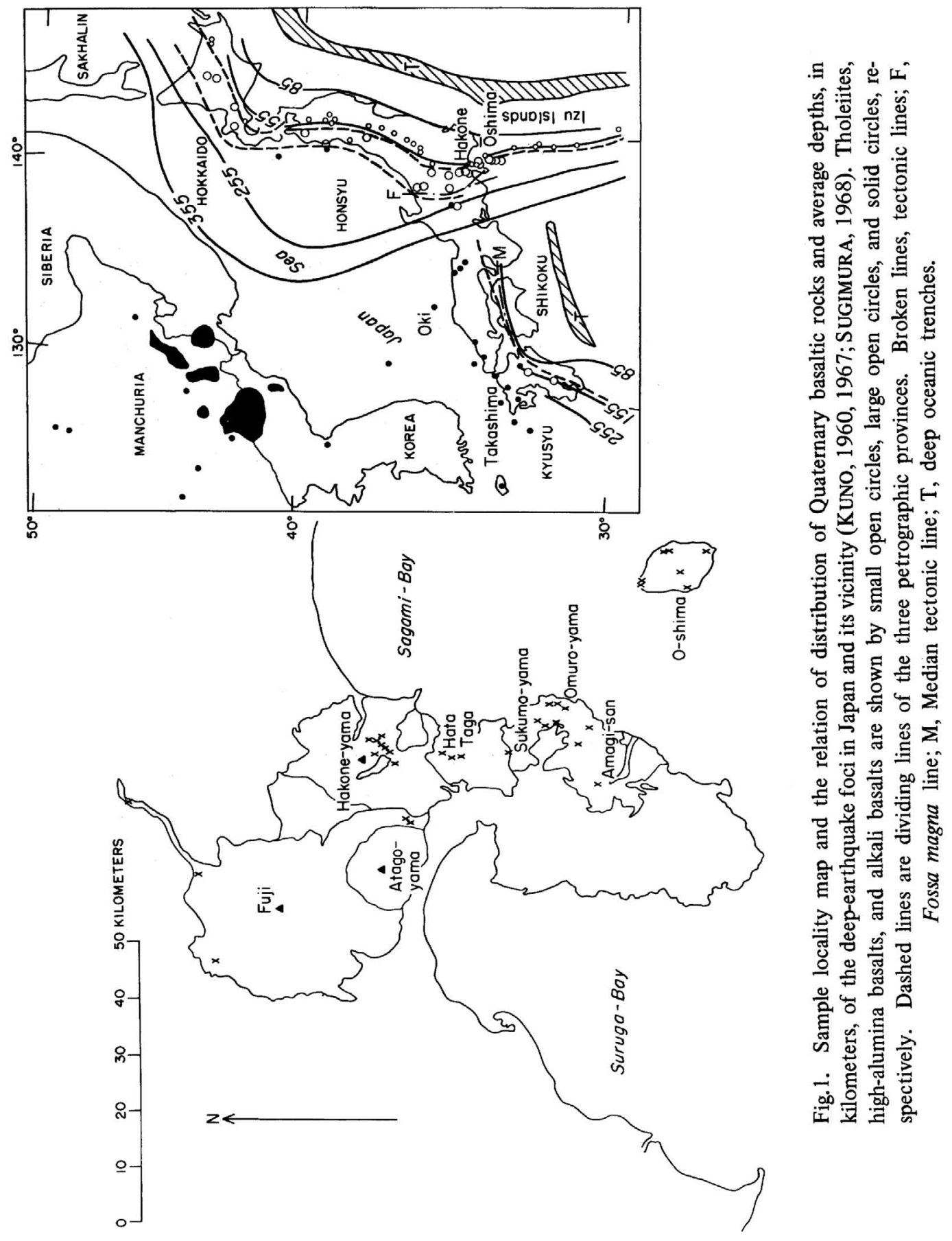


derived from each of the three types of primary basalt magma.

Samples studied are tholeiites from O-shima volcano of the Izu Islands; tholeiites from Taga volcano; basalts, andesites, and a dacite of tholeiite series from Hakone volcano; high-alumina basalts from Fuji volcano (or Huzi) and Sukumo volcano belonging to the Omuro-yama volcano group; and basalts, andesites, and dacites of calc-alkali rock series which belong to the high-alumina rock series of Amagi and Omuro-yama* volcanoes. Sample localities are given in Tables 1-4 and Figure 1. A summary of the geology of this area may be found in KUNo (1962) and TsuYA (1937). O-shima volcano is underlain by the Okata Basalt Group (samples Os1 and Os2) and the Hudeshima Basalt Group of late Pliocene age. These are in turn underlain by a lower Miocene complex of andesites and basalts. Mihara-yama, the main cone of O-shima volcano, is a stratovolcano of basaltic lavas and pyroclastics of tholeiitic composition (samples Os3 to Os7).

The geology and petrology of Hakone area was studied in detail by KunO (1950). The Hata Basalt Group of late Pliocene age (samples Hat1 and Hat2) comprises one of the Miocene to Pliocene basement volcanoes. Taga volcano (sample Tag) appeared in early Pleistocene to the south of the present Hakone volcano. Hakone volcano (middle to late Pleistocene) was built in three distinct stages. The first stage, the old Somma lavas (KuNo, 1950, 1962), began with eruption of basalt agglomerate and lava (sample K1), followed by eruption of pyroxene andesite (samples K2 to K4). After caldera formation, young Somma lavas of andesitic and dacitic composition (samples K5 and K6) were erupted to constitute the second stage. Formation of the central cones of pyroxene andesite (samples $\mathrm{K} 8$ and $\mathrm{K} 9$ ) was the third stage. According to Kuno (1950), the old Somma and young Somma lavas are tholeiite (pigeonitic rock) series produced by fractionation of a primary tholeiitic magma; sample Hat1 is compositionally closest to the primary magma. The lavas of the central cones are calc-alkali (hypersthenic) rock series which were probably formed by fractionation and crustal contamination of a tholeiitic primary magma.

The geology of Fuji Volcano was studied extensively by TsuYA (see KuNO, 1962, for summary). The old Fuji volcano (samples F1 to F3) formed a little earlier than the third stage of Hakone (KunO, 1962) largely on a basement of lower Miocene volcanic rocks (Misaka Group). These were subsequently covered by lavas from the recent Fuji volcano (samples F4 and F5). The lavas of Fuji (old and recent) are mostly olivine basalts and pyroxene olivine basalts of the high-alumina basalt series (KUNO, 1960).

The geology of Omuro-yama and Amagi volcanoes is summarized by Kuno (1962) and Kurasawa (1959). An outstanding feature of Omuro-yama and Amagi volcanoes

* The Omuro-yama is the one in Izu Peninsula (KUNO, 1962, page 60) and it should not be confused with the Omuro-yama of Fuji, a parasitic cone of the mountain (KUNO, 1962, page 86). 
is the existence of a number of vents. The formation of Amagi started in the Pleistocene on Tertiary basement rocks. Togasa-yama lava, an andesite (sample Am1), was erupted in late Pleistocene. In the Holocene, basalt, andesite, and dacite (samples Om1-6, Am2 and 3) were erupted from numerous vents. Sample Suk of Sukumoyama is a primary high-alumina olivine basalt, but most of the rocks of Omuro-yama and Amagi groups are calc-alkali rocks of high-alumina series. KunO (1954, 1960) indicated that the calc-alkali rocks of Omuro-yama and Amagi were produced by fractionation of a parental high-alumina basalt magma contaminated by quartz diorite or granodiorite. The olivine basalt of Sukumo-yama may approach most nearly the composition of the parental high-alumina basalt.

Samples were collected by B. R. DoE and M. TATSUmoto under the guidance of H. Kuno, University of Tokyo, and H. Kurasawa, Geological Survey of Japan.

\section{Procedures}

Large samples were sawed into small cubes (about $3 / 4$ cubic inch) and only those representing the interior of the original were used for analyses. The surfaces of cubes were repeatedly cleaned with an ultrasonic vibrator with distilled water and with $6 \mathrm{~N}$ $\mathrm{HC} 1$ for $1 / 2$ minute followed by rinsing with distilled water. The cubes were then crushed by a diamond steel mortar and powdered by a carbide steel crusher "Shatterbox," in the lead-free laboratory of the U. S. Geological Survey.

Lead isolation for the determination of isotopic composition was similar to that reported previously (ТАтsUмото, 1966 b). Since isotopic fractionation may significantly be affected by the amount of lead loaded on the filaments (DoE et al., 1967) lead concentrations were determined first. Lead for isotopic composition was then pyrochemically extracted from a sample amount equivalent to $25 \mu \mathrm{g}$ of lead. This was done by heating $\left(\sim 1,200^{\circ} \mathrm{C}\right)$ a mixture of nine parts of powdered sample and one part of graphite powder in vacuum $\left(10^{-3} \sim 10^{-6} \mathrm{~mm} \mathrm{Hg}\right)$ for ten hours. No measurable fractionation of lead resulting from pyrochemical extraction was observed when the sample was heated higher than $1,100^{\circ} \mathrm{C}$ for longer than five hours. The volatilized lead was deposited on a cold finger and was purified further by barium coprecipitation in conc. $\mathrm{HNO}_{3}$ media and by a conventional dithizone extraction (TiLToN et al., 1955). The lead recoveries, estimated from the amount of dithizone solution required at the extraction stage, were more than $95 \%$ for all samples. The total laboratory contamination contributed to the composition run was less than $0.02 \mu \mathrm{g}$ per analysis.

The concentration of lead, uranium and thorium was determined by isotope dilution (TATSUmoto, 1966a). The laboratory lead contamination for the concentration analyses which involve chemical decomposition by $\mathrm{HF}$ and $\mathrm{HC}_{4} \mathrm{O}_{4}$ under the open laboratory atmosphere was checked with every six samples and ranged 0.025 to $0.045 \mu \mathrm{g}$ per analysis. The concentrations are believed to be accurate within two percent and the concentration ratios may be known within one percent because of the 
use of combined spike solution of enriched ${ }^{206} \mathrm{~Pb},{ }^{235} \mathrm{U}$ and ${ }^{230} \mathrm{Th}$.

The mass spectrometry used for the measurement of the lead isotope ratios was the same as reported earlier (ТАTSUмото, 1966a). It was a 12-inch mass spectrometer utilizing a single Re-filament source, rapid scanning by switching of the magnet current, an expanded scale recorder, and Faraday cup collector. The sample was run as $\mathrm{PbS}$ on a Re-filament at $840^{\circ} \mathrm{C} \pm 5^{\circ} \mathrm{C}$. No discrimination factor was applied to the raw data. Repeated determination for $20 \mu \mathrm{g}$ of CIT Shelf Standard during the course of this investigation was: ${ }^{206} \mathrm{~Pb} /{ }^{204} \mathrm{~Pb}=16.751 \pm 0.015 ;{ }^{206} \mathrm{~Pb} /{ }^{207} \mathrm{~Pb}=1.0700 \pm 0.0006$; ${ }^{206} \mathrm{~Pb} /{ }^{208} \mathrm{~Pb}=0.4542 \pm 0.0006$. However, sample precision should be calculated from the actual sample run because with the single-filament method, foreign elements may cause variations in fractionation. The precision (as standard deviation) of a single analysis calculated from 26 duplicates and three triplicate analyses is: $\pm 0.12 \%$ for ${ }^{206} \mathrm{~Pb} /{ }^{204} \mathrm{~Pb}, \pm 0.057 \%$ for ${ }^{206} \mathrm{~Pb} /{ }^{207} \mathrm{~Pb}$, and $\pm 0.11 \%$ for ${ }^{206} \mathrm{~Pb} /{ }^{208} \mathrm{~Pb}$.

All samples used in this study are Quaternary in age; therefore no correction of the isotopic composition of lead for uranium- and thorium- produced lead accumulated after the lava eruption was necessary.

\section{RESULTS}

Analytical results are listed in Table 1 for samples from O-shima volcano (tholeiitic), in Table 2 for samples from Hakone area (tholeiitic and calc-alkali), in Table 3 for samples from Fuji volcano (high-alumina), and in Table 4 for samples from Amagi and Omuro-yama area (high-alumina and calc-alkali).

Concentrations: The concentrations of lead, uranium and thorium are shown on a histogram (Fig. 2). The lead concentration in Japanese tholeiites (Tables 1 and 2) varies from 1.4 to $6.4 \mathrm{ppm}$. The concentration is much higher than those of abyssal tholeiites (TATsumoto, 1966 b) and of Hawaiian tholeiites (TATsumoto and KNIGHT, 1968). The uranium concentration of Japanese tholeiites ranges from 0.04 to 0.26 ppm. The concentration is slightly higher than those of abyssal tholeiites, but comparable to those of Hawaiian tholeiites. Hence the ${ }^{238} \mathrm{U} /{ }^{204} \mathrm{~Pb}$ (observed $\mu$ ) of 1.9 to 6.9 in Japanese tholeiites is far lower than those of Hawaiian rocks. The observed ${ }^{238} \mathrm{U} /{ }^{204} \mathrm{~Pb}$ values in the Japanese andesites in both the tholeiite and high-alumina basalt series, except a few andesites of calc-alkali rock series, are also lower than 8.75 which is calculated from the isotopic composition of lead in a closed system (apparent $\mu$ ). The thorium concentrations of Japanese tholeiites range from 0.09 to $0.55 \mathrm{ppm}$ and are lower than those of Hawaiian tholeiites but slightly higher than those of abyssal tholeiites. The ${ }^{232} \mathrm{Th} /{ }^{238} \mathrm{U}$ (observed $\kappa$ ) ratios of Japanese tholeiites (1.3 to 2.5 ) are lower than those of Hawaiian tholeiites (about 3 ) but similar to abyssal basalts (about 2) (TATsumoto, 1966 b). These low observed values of ${ }^{238} \mathrm{U} /{ }^{204} \mathrm{~Pb}$ and ${ }^{232} \mathrm{Th} /{ }^{235} \mathrm{U}$ for the tholeiite appear to be very significant to the basalt genesis problem and will be 
Isotopic composition of volcanic rocks

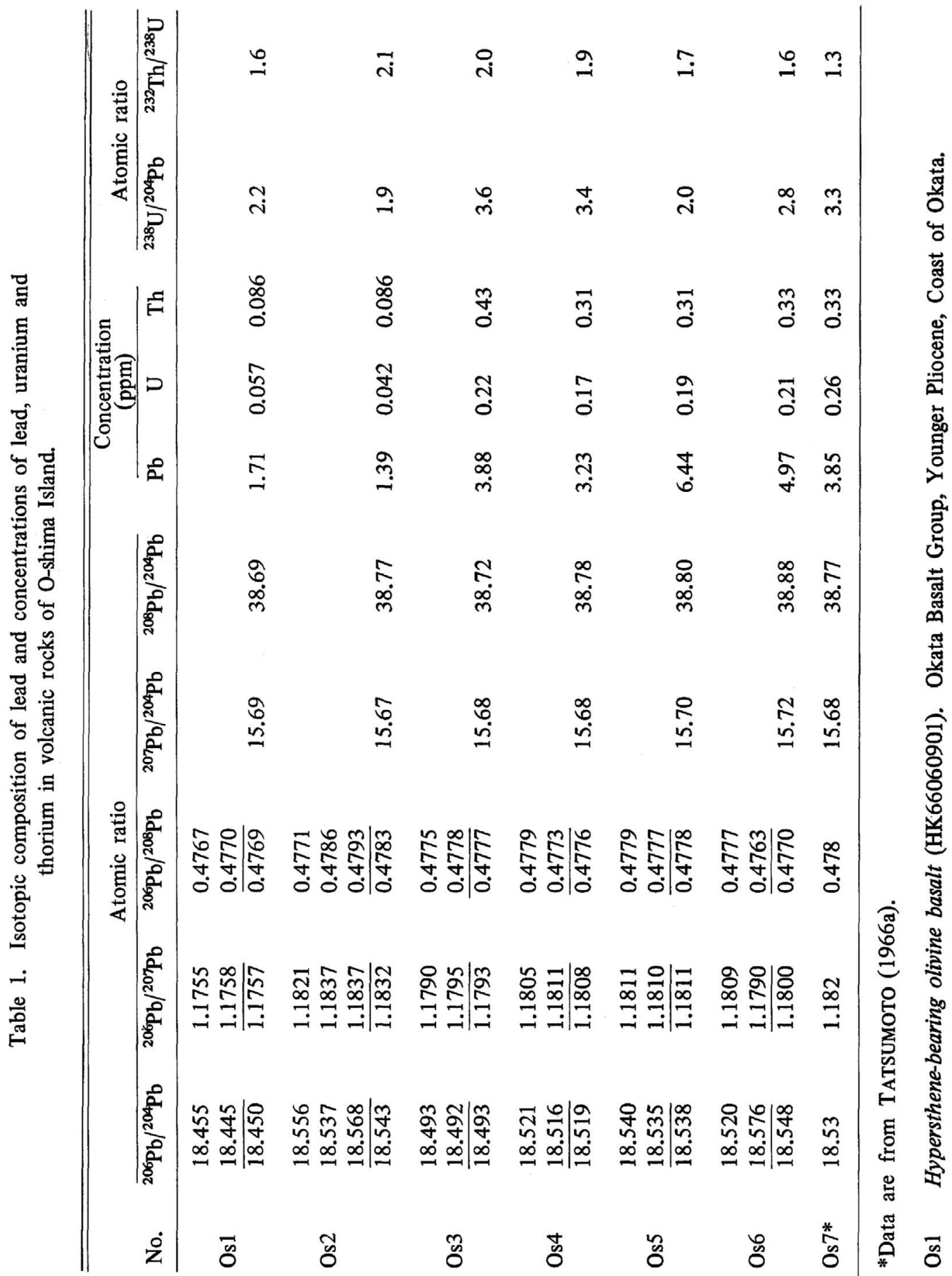




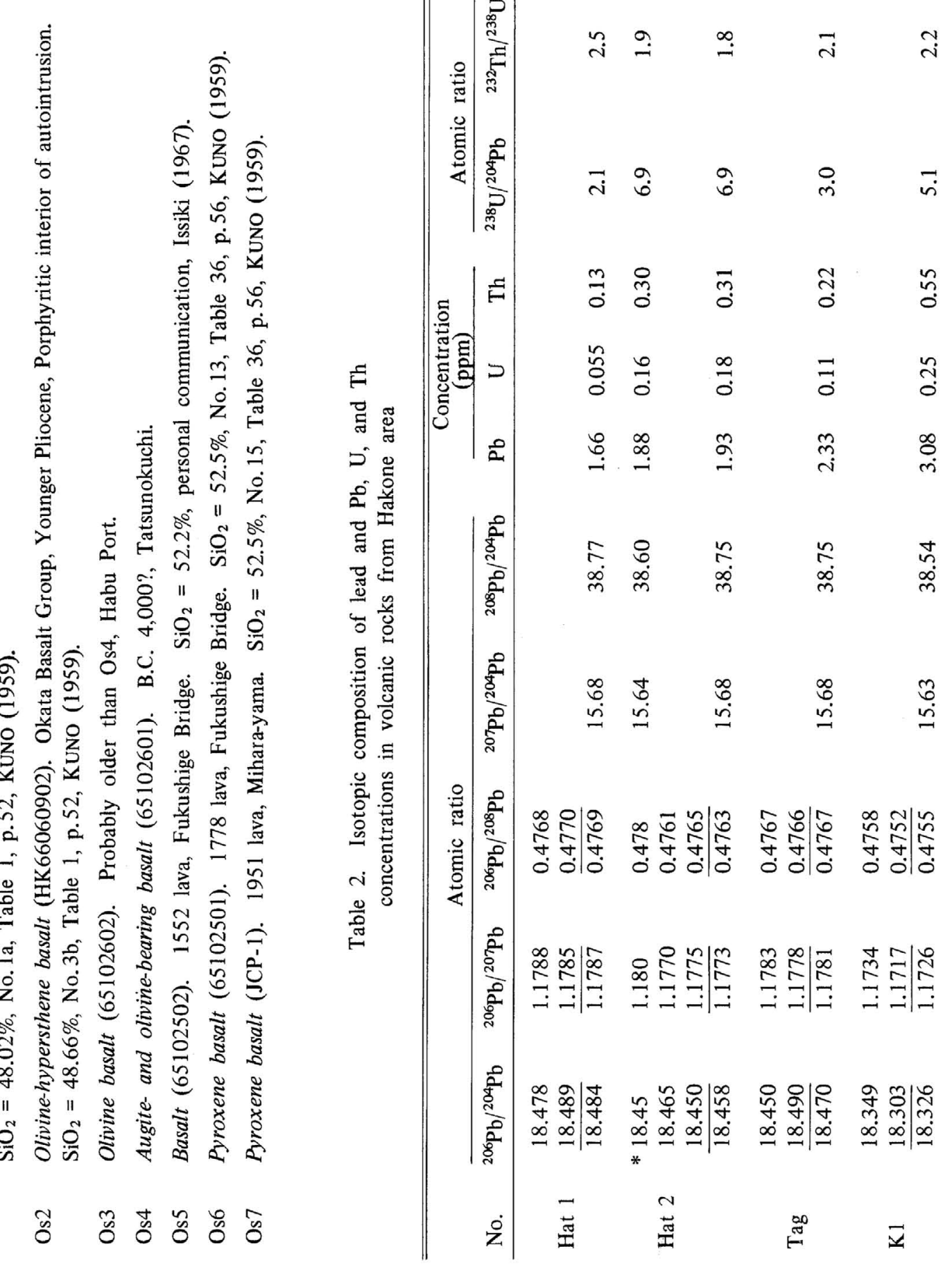




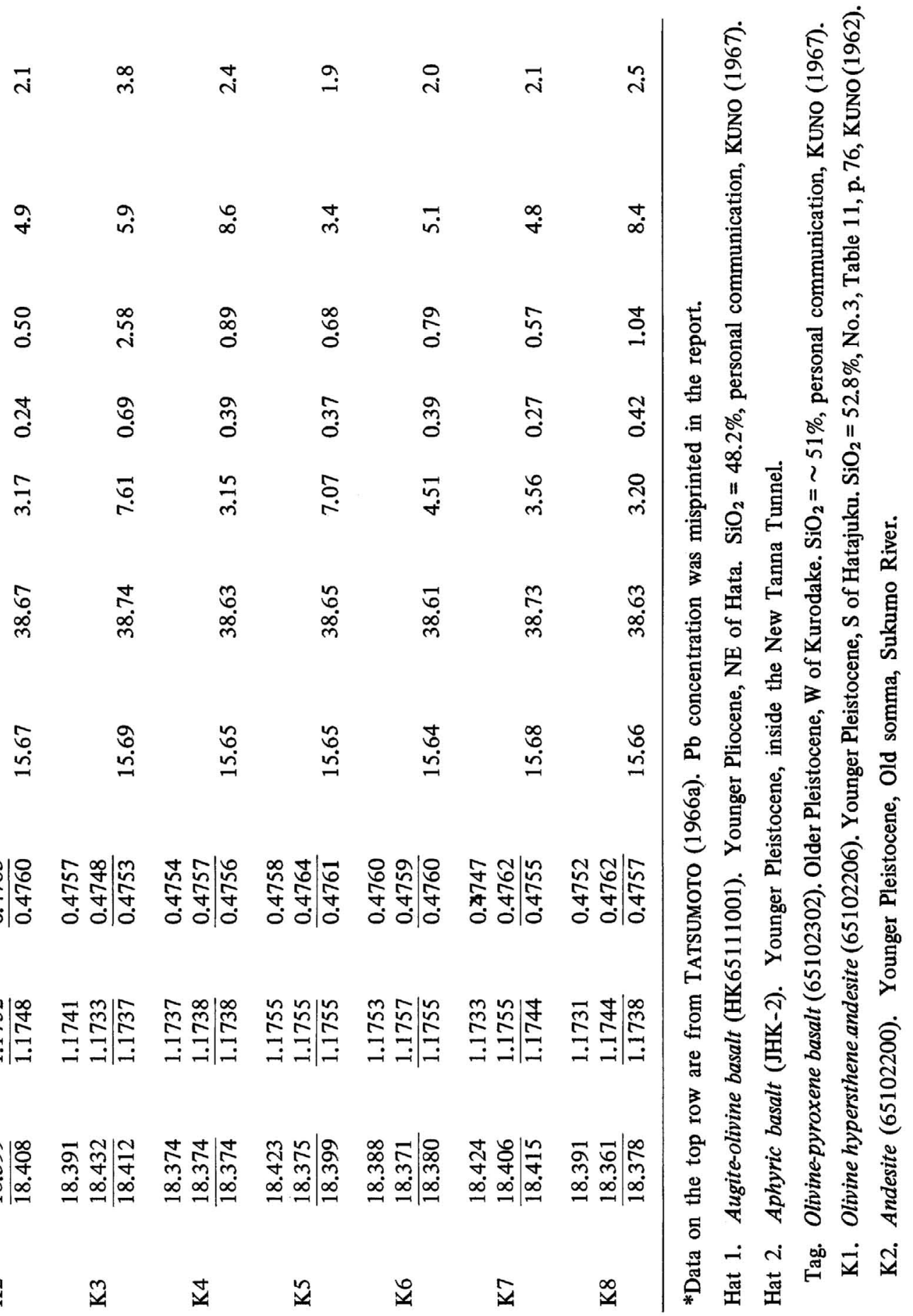



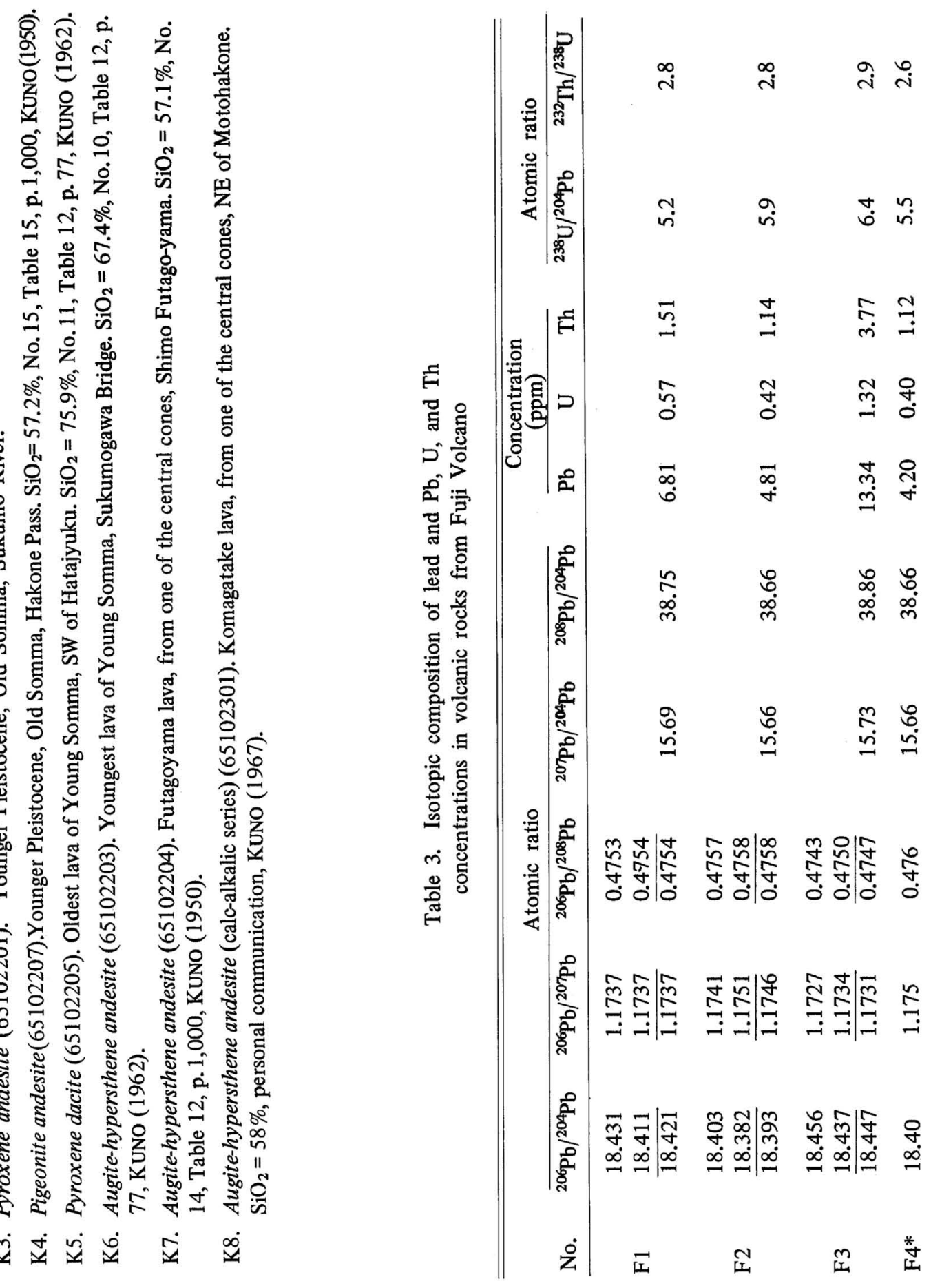

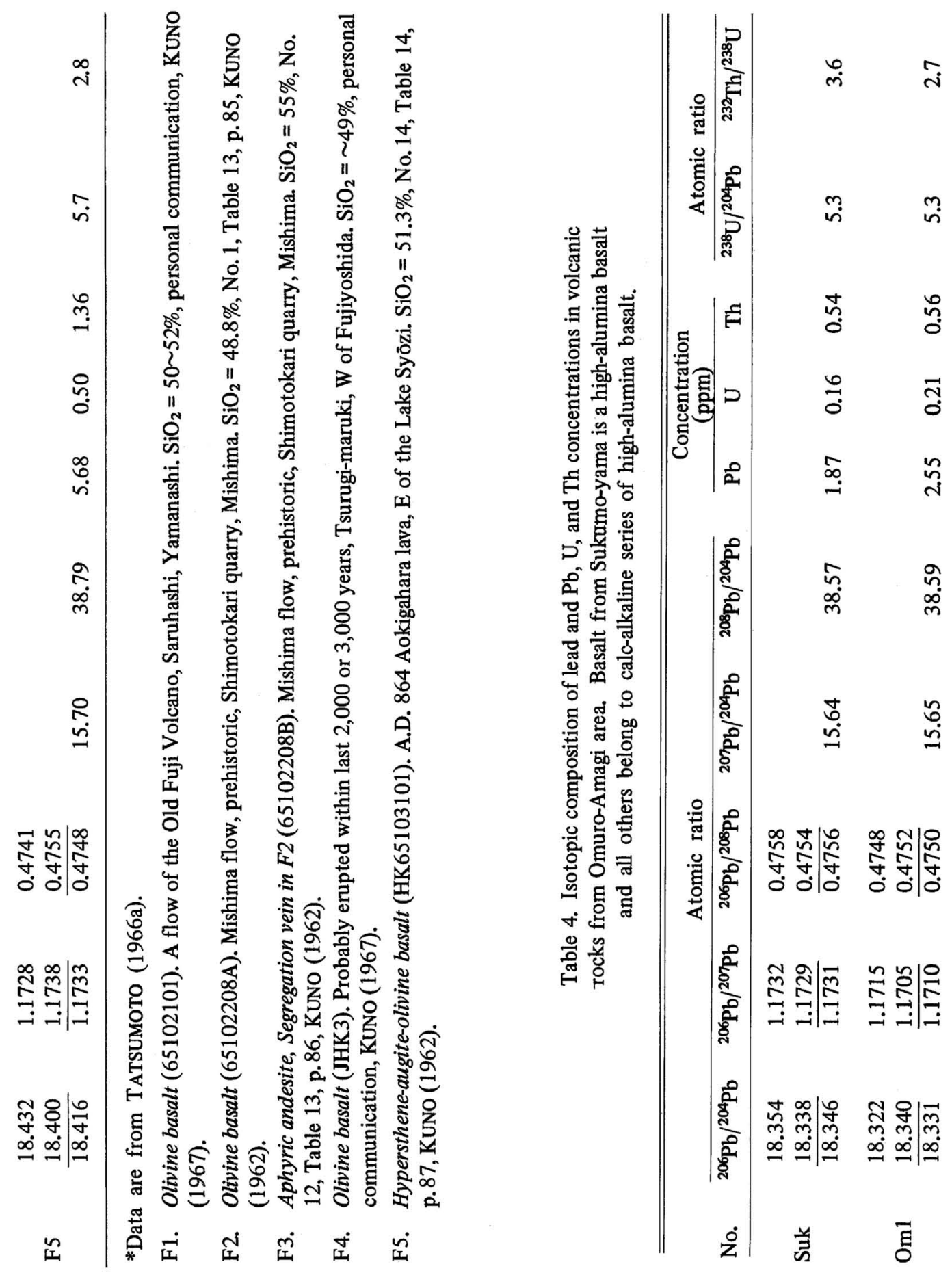
M. TATSUMOTO and R. J. KNIGHT

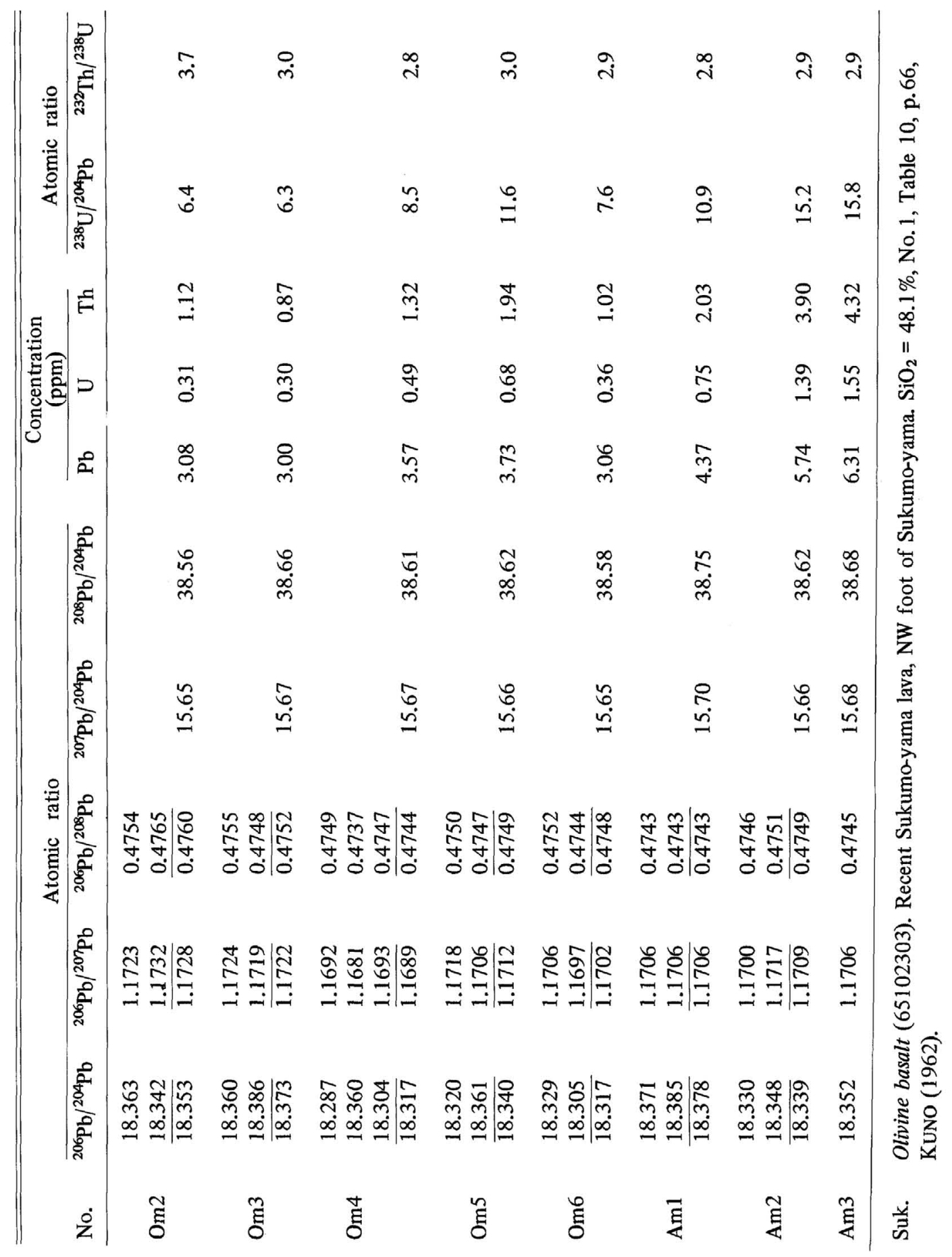




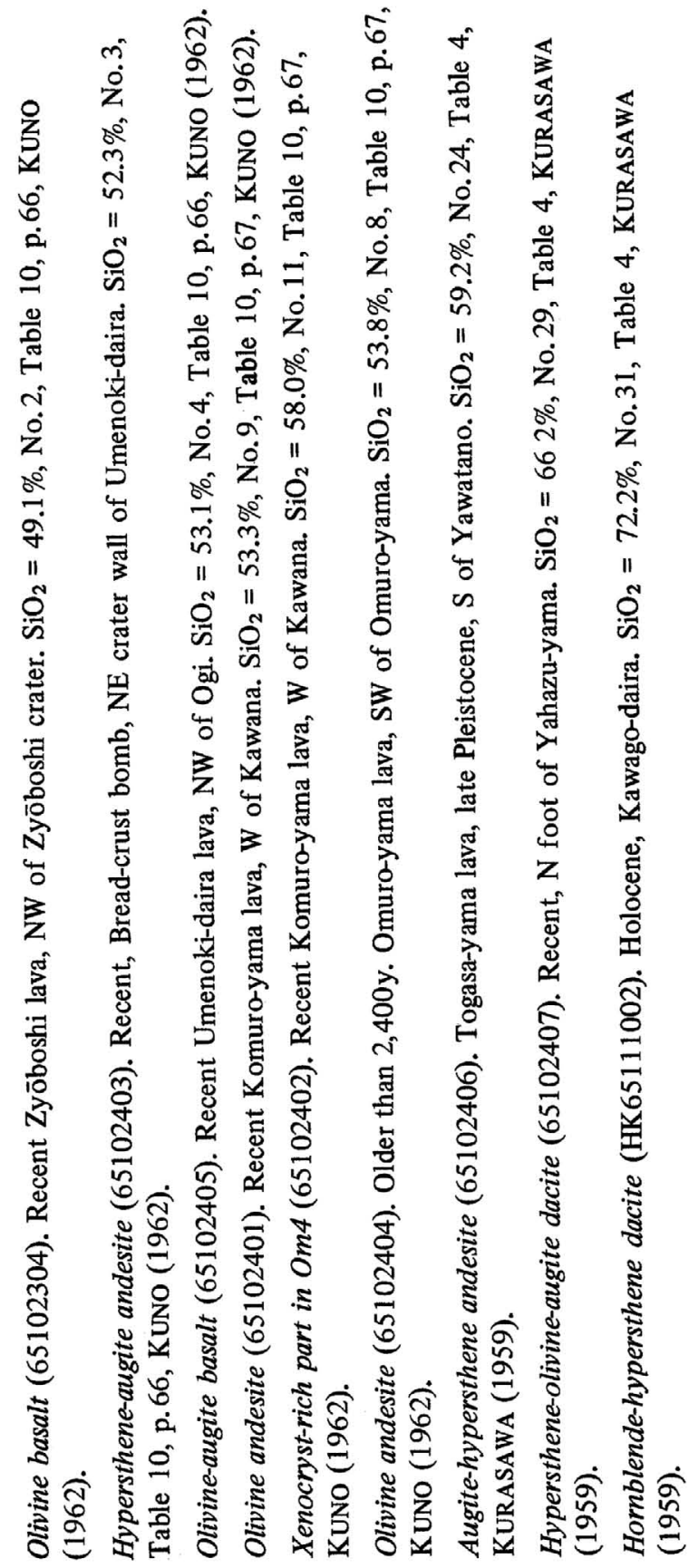

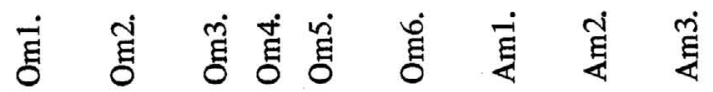


discussed later.

The lead concentrations of the high-alumina basalts of Japan (Tables 3 and 4) range from $1.9 \mathrm{ppm}$ (Sukumo-yama lava) to $6.81 \mathrm{ppm}$. These values are silimar to those of tholeiites and alkali olivine basalts from Japan. Uranium concentrations of the high-alumina basalts range from 0.16 to $0.75 \mathrm{ppm}$ and, except for those of Sukumoyama, are slightly higher than those of Japanese tholeiites but similar to the Japanese alkali basalts (KuRASAwA, 1968). The thorium concentrations of the high-alumina basalts, 0.57 to $1.51 \mathrm{ppm}$, are higher than those of tholeiites but lower than those of alkali basalts. The observed ${ }^{238} \mathrm{U} /{ }^{204} \mathrm{~Pb}$ and ${ }^{232} \mathrm{Th} /{ }^{238} \mathrm{U}$ ratios of the Japanese highalumina basalts range from 4.2 to 6.8 and 2.6 to 3.6 respectively. These ratios are intermediate between those of tholeiites and alkali basalts from Japan but still lower than the value expected from the isotopic composition of lead. The lead, uranium,

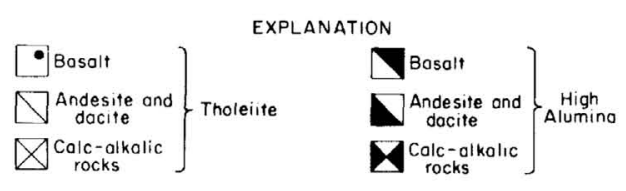

Alkalı basalt (Kurasawa, 1968)
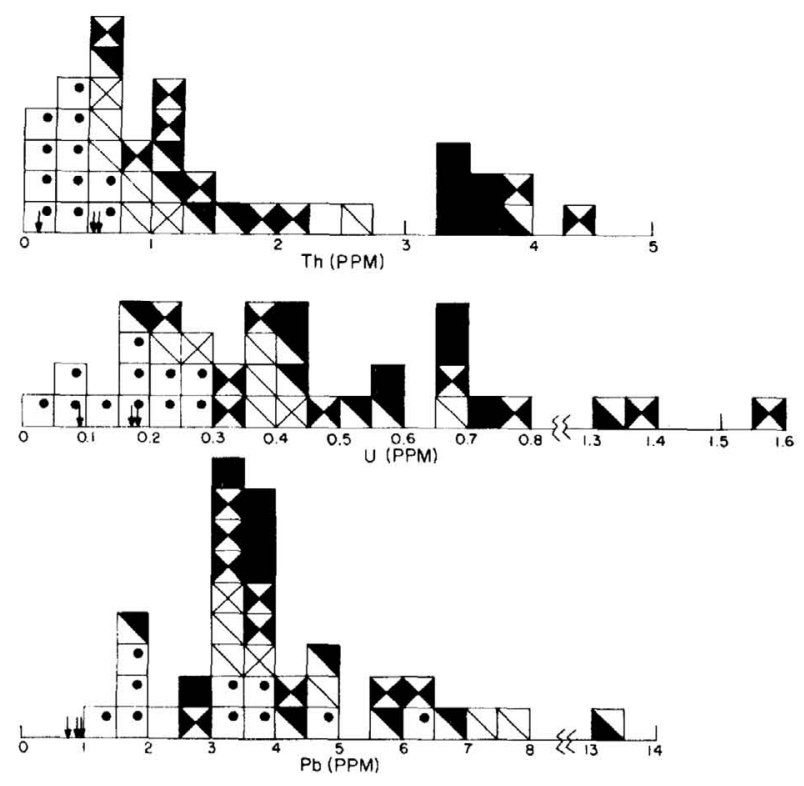

Fig.2. $\mathrm{Pb}, \mathrm{U}$, and $\mathrm{Th}$ concentrations in Japanese volcanic rocks. Single arrow indicates average value of six abyssal basalts (TATSUMOTO, 1966 b). Double arrow indicates average of Hawaiian tholeiites (TATSUMOTO and KNIGHT, 1968). 
and thorium concentrations in andesite and dacite are higher than those in the parental basalt but there are no clear differences in the concentrations between derivatives of tholeiite and high-alumina basalt series and those of the calc-alkali rock series.

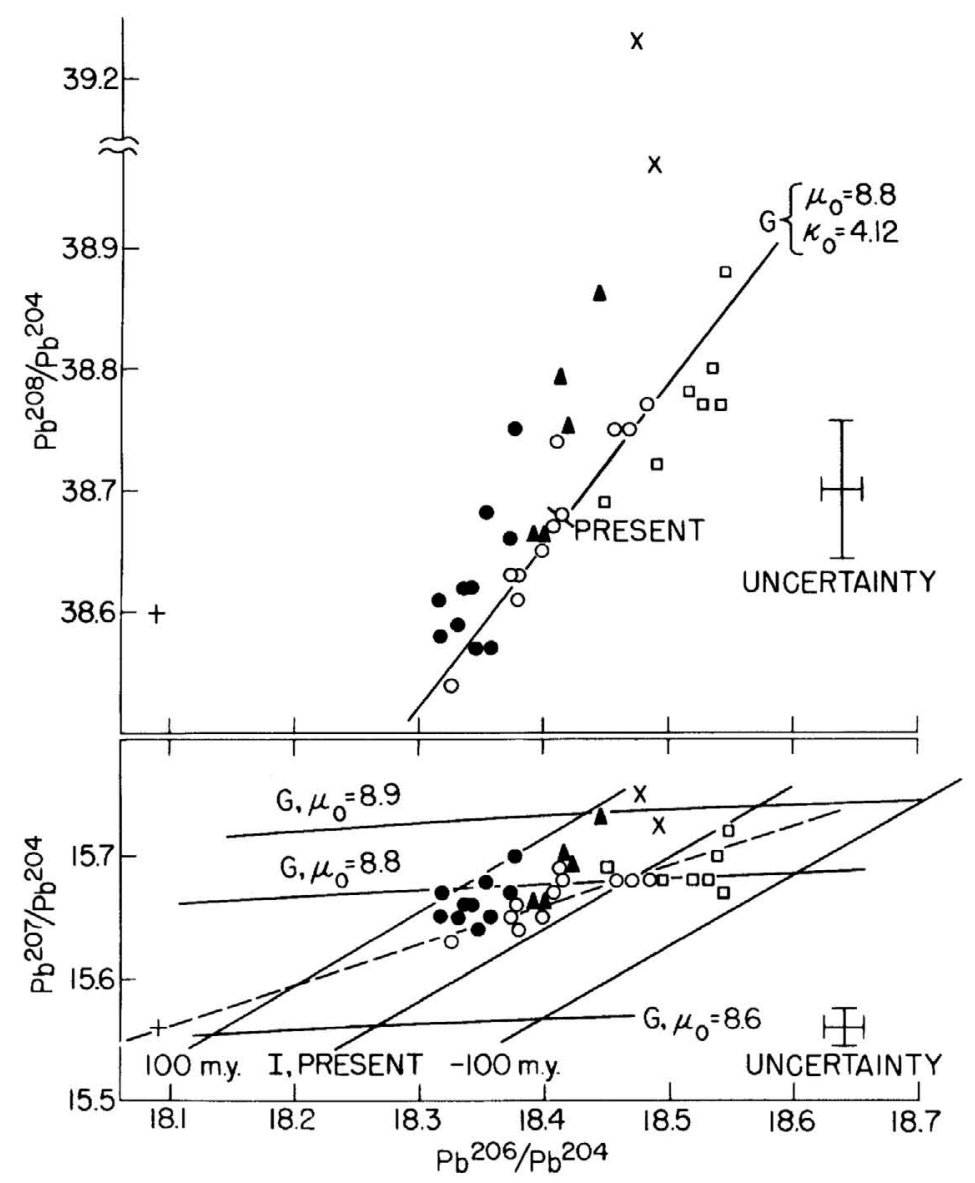

Fig.3. Composite diagram of ${ }^{206} \mathrm{~Pb} /{ }^{204} \mathrm{~Pb}$ vs. ${ }^{207} \mathrm{~Pb} /{ }^{204} \mathrm{~Pb}$ and ${ }^{206} \mathrm{~Pb} /{ }^{204} \mathrm{~Pb}$ vs. ${ }^{208} \mathrm{~Pb} /$ ${ }^{204} \mathrm{~Pb}$ for Quaternary volcanic rocks from Central Honshu. Open squares and circles are for the tholeiite series from O-shima and Hakone-Hata-Taga areas, respectively; solid triangles and circles are for high-alumina series from Fuji and for high-alumina and its calc-alkali rock series from Omuro-Amagi area, respectively. Leads of pyroxene andesites (X) from Yatsuga-take and On-take (TATSUMOTO, 1969) and average lead of alkali olivine basalts $(+)$ from Oki-dogo (TATSUMOTO, 1966a; and KURASAWA, 1968)are also plotted for comparison. Lines labeled by $\mathrm{G}$ and $\mathrm{I}$ are primary growth curves and primary isochrons, respectively. A secondary isochron $3.6 \mathrm{~b} . \mathrm{y}$. is indicated by a dashed line. Indicated uncertainties are \pm one standard deviation for duplicate analyses. 
Isotopic composition of lead: The isotopic compositions of lead in Japanese rocks of the tholeiite and the high-alumina basalt series, including their calc-alkali derivatives (Tables 1, 2, 3 and 4) are compared in Fig.3, which is a combined diagram of ${ }^{206} \mathrm{~Pb} /{ }^{204} \mathrm{~Pb}$ vs. ${ }^{207} \mathrm{~Pb} /{ }^{204} \mathrm{~Pb}$ (lower part) and ${ }^{206} \mathrm{~Pb} /{ }^{204} \mathrm{~Pb} v$ s. ${ }^{208} \mathrm{~Pb} /{ }^{204} \mathrm{~Pb}$ (upper part). Primary growth curves $(G)$ are shown for a chemically closed system with present day ${ }^{238} \mathrm{U} /{ }^{204} \mathrm{~Pb}$ ratio $\left(\mu_{0}\right)$ of $8.6,8.8$, and 8.90 since the earth formed (4.55b.y. ago). The primary isochrons (I) which are time intercepts of the growth curves for a chemically closed system with initial ${ }^{238} \mathrm{U} /{ }^{204} \mathrm{~Pb}$ values are also given for the present and \pm 100 m.y. In the upper part of Fig.3, the primary growth curve $(G)$ is shown for ${ }^{238} \mathrm{U} /{ }^{204} \mathrm{~Pb}=8.8$ and ${ }^{232} \mathrm{Th} /{ }^{238} \mathrm{U}=4.12$. Parameters used in this paper are: the primordial lead (MURTHY and PATTERSON, 1962); ${ }^{206} \mathrm{~Pb} /{ }^{204} \mathrm{~Pb}=9.56,{ }^{207} \mathrm{~Pb} /{ }^{204} \mathrm{~Pb}=$ 10.42 , and ${ }^{208} \mathrm{~Pb} /{ }^{204} \mathrm{~Pb}=29.71$; age of the earth $=4.55 \times 10^{9} \mathrm{y}$; decay constant for ${ }^{238} \mathrm{U}=0.15369 \times 10^{-9} \mathrm{y}^{-1}$, for ${ }^{235} \mathrm{U}=0.97216 \times 10^{-9} \mathrm{y}^{-1}$, and for ${ }^{232} \mathrm{Th}=0.048813$ $\times 10^{-9} \mathrm{y}^{-1} ;{ }^{238} \mathrm{U} /{ }^{235} \mathrm{U}$ atomic ratio $=137.8$. The secondary zero isochron shown by dashed line in Fig. 3 is for 3.6b.y. In the figure, data of pyroxene andesites from the central part of Honshu (TATSUMOTo, 1969) and Kurasawa's (1968) for Japanese alkali olivine basalts are also plotted for comparison.

The isotopic results obtained in this study in general confirm the result of a previous study (ТАтsumoto, 1966a). The lead isotopic composition of Japanese tholeiitic and high-alumina volcanic rocks lie between the primary growth curves of ${ }^{238} \mathrm{U} /{ }^{204} \mathrm{~Pb}=8.70$ and 8.85 and between +100 to -100 m.y. primary isochrons. The most significant feature of these data is that the rediogenic character of the lead decreases from the Pacific side to the Japan Sea side of the Japanese Islands. The O-shima basalts, except one sample, have a slight excess of ${ }^{206} \mathrm{~Pb}$ compared to the primary system. The leads of a primary tholeiite from O-shima and tholeiites from Hata and Taga volcanoes are close to the primary isochron, but other leads of tholeiite and high-alumina basalt series are deficient in ${ }^{206} \mathrm{~Pb}$. The $\mu_{0}$ values of the primary growth curve on which Japanese basalt data fit decrease gradually from 8.8 for O-shima to 8.6 for Oki-dogo, and farther west, to 8.45 for Takashima trachybasalt (KuRASAWA, 1968). This trend defines a 3.6b.y. secondary isochron.

In detail, the lead isotopic compositions of rocks from each volcano show a range beyond the experimental uncertainty. The lead of the Okata Basalt Group, of late Pliocene age (Os1), is the least radiogenic among those of the O-shima tholeiites and is similar to that of Hata basalts. In the same volcano the leads of the later stage basalts are slightly more radiogenic than those of the older group. The lead of a porphyritic interior (Os2) of the autointrusion in the Okata Basalt Group is more radiogenic than that of Okata Basalt (Os1) and similar to that of the later stage basalts.

The Hata and Taga basalts which are considered by Kuno (1959) to be compositionally near the parent magma of volcanic rocks from the Hakone area have lead 
isotopic compositions near a zero isochron as does that of the Okata basalt of O-shima, whereas the lead from old Somma lava (K1) from Hakone is the most unradiogenic in this area. The leads of andesite and dacite of the later stage of Hakone are more radiogenic than that of the old Somma basalt but less radiogenic than those of Hata and Taga basalt. The leads from the calc-alkali (hypersthenic) rock series from the cones of the Hakone Volcano are similar to those of the tholeiitic (pigeonitic) ones from the same volcano.

The leads of the "most primitive" high-alumina basalt from Fuji (samples F2 and F4) and from Sukumo (sample Suk) are similar to those of the Hakone volcanics and lie on the trend lines (the secondary isochron in the lower part of Fig. 3 and a growth curve in the upper part of the figure), but other leads of the high-alumina basalt series (the three samples from Fuji and all other calc-alkali rock series from Omuro-yama and Amagi) are rich in ${ }^{207} \mathrm{~Pb}$ and ${ }^{208} \mathrm{~Pb}$, and plot above the trend lines. This probably is due to crustal contamination, because the apparent $\mu_{0}$ of the crust is higher than that of the upper mantle.

The leads of the autointrusion (Os2) and segregation vein (F3) are more radiogenic than those of the main body of olivine basalts (Os1 and F2). This difference is well beyond any reasonable experimental error, and may be due to assimilation of a more radiogenic lead by some mechanism such as volatile transfer.

\section{DiscUSSION}

Some geologists studying basalts from oceanic areas (Powers, 1935, 1955, Macdonald, 1949; Macdonald and Katsura, 1961; ENGEl and EnGEL, 1964 a, 1964b; and ENGEL et al., 1965) have concluded that tholeiitic basalts represent the primary magma from which alkali basalt is derived by a process of fractional crystallization. On the other hand, Kuno and his colleagues (KunO, 1959; KusHIRo and Kuno, 1963), who studied mainly Cenozoic volcanic rocks of Japan, suggested that different magma types are generated in the mantle by fractional melting of peridotite under different conditions of pressure and temperature.

Results of high-pressure experiments (KUSHIRo, 1965, 1968; GrEEN and RiNGwOoD, 1967; MACGREGOR, 1955, 1968) which investigated the crystal-liquid equilibria of the mineral components pertinent to mantle composition appear to be consistent with KuNO's interpretation. However, the experimental petrologists seem to disagree as to the principal mechanism that produces different types of magma. Some (KusHIRo, 1968; MACGREGOR, 1968) suggest that partial melting of mantle peridotite at different pressure (depth) results in the different magma types, but others (YoDER and TILLEY, 1962; O'HARA and YoDER, 1967; GREEN and RINGWOOD, 1967) suggest that fractional crystallization of a primary magma at different pressures is a prime cause for generation of these types. 
Among geochemists studying trace element abundance and strontium and lead isotopes, GAST (1968) supports the former group of experimental petrologists in the sense of advocating different degree of partial melting at different points in the zone of melting, but Tatsumoto (1966b) and TaTsumoto and KNight (1968) suggested the possibility of comagmatic generation of alkali basalt and tholeiite for a tholeiite-alkali basalt pair from a single locality based on lead isotopic studies. However, the basalts from the traverse of the Japanese arc are a different problem from those from a single volcanic source. The petrological provinces of tholeiite, high-alumina basalt, and alkali basalt are distinct in the Japanese Island arcs and the lead isotopic differences in Japanese volcanics must be considered in this context.

As previously stated, the leads of primitive Japanese basalts show a smooth decreasing trend in ${ }^{206} \mathrm{~Pb} /{ }^{204} \mathrm{~Pb} v$ s. ${ }^{207} \mathrm{~Pb} /{ }^{204} \mathrm{~Pb}$ (Figs.3 and 5) from the O-shima tholeiites through the tholeiites from Hata and Taga volcanoes and the high-alumina basalts from Fuji and Sukumo to Oki-dogo basalts and farther westward to Takashima alkali basalts. In contrast to the positive correlation for ${ }^{206} \mathrm{~Pb}-{ }^{207} \mathrm{~Pb}$, the relation of
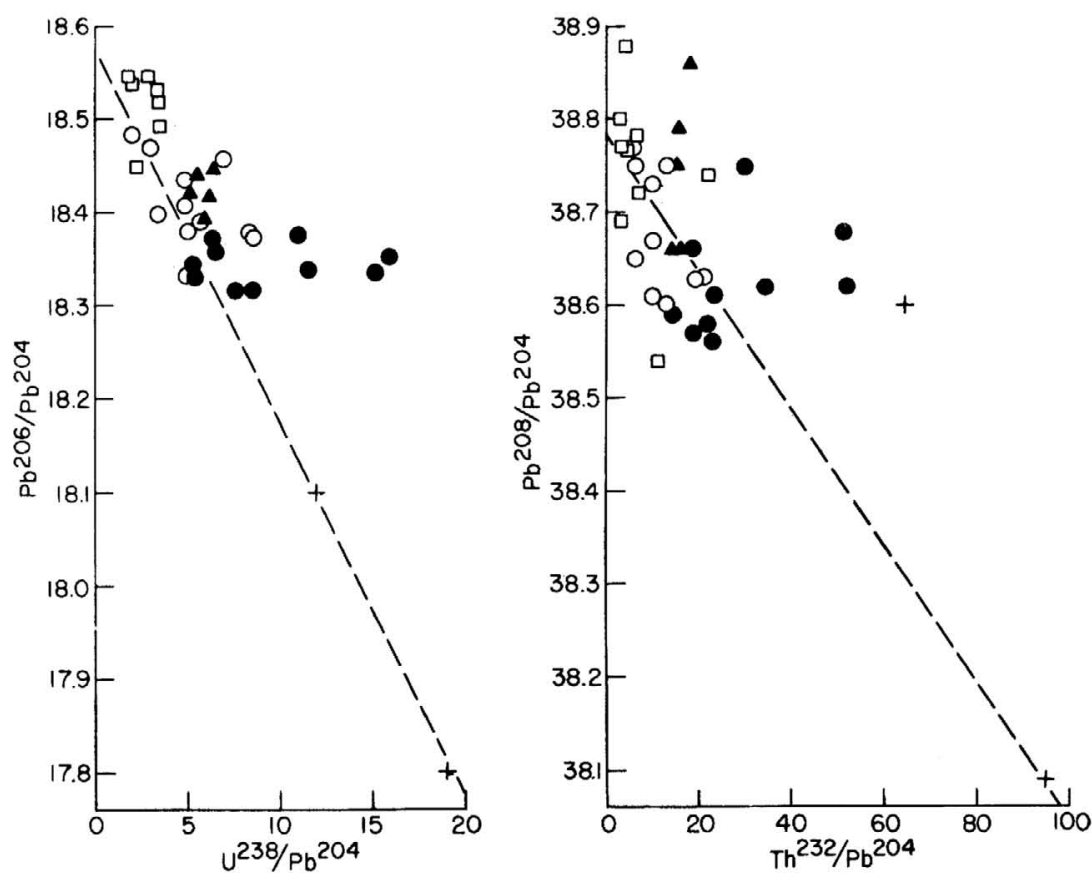

Fig.4. ${ }^{206} \mathrm{~Pb} /{ }^{204} \mathrm{~Pb}$ vs. observed ${ }^{238} \mathrm{U} /{ }^{204} \mathrm{~Pb}$ and ${ }^{208} \mathrm{~Pb} /{ }^{204} \mathrm{~Pb}$ vs. observed ${ }^{232} \mathrm{Th} /{ }^{204} \mathrm{~Pb}$ indicating inverse correlation of parent-daughter. The inverse correlation on ${ }^{208} \mathrm{~Pb}^{232} \mathrm{Th}$ plot is not as distinct as that on ${ }^{206} \mathrm{~Pb}^{238} \mathrm{U}$ plot. Inverse correlation is indicated by broken lines which connect between tholeiites of Hata-Taga area and trachybasalt of Takashima. Symbols are the same as those on Fig.3. 
parent and daughter nuclides shows an inverse correlation given in Fig. 4 as the plots of ${ }^{238} \mathrm{U} /{ }^{204} \mathrm{~Pb}$ (observed $\mu$ ) vs. ${ }^{206} \mathrm{~Pb} /{ }^{204} \mathrm{~Pb}$ and ${ }^{232} \mathrm{Th} /{ }^{204} \mathrm{~Pb}$ (observed $\mu \times \kappa$ ) vs. ${ }^{208} \mathrm{~Pb} /{ }^{204} \mathrm{~Pb}$. If $\mathrm{U} / \mathrm{Pb}$ and $\mathrm{Th} / \mathrm{Pb}$ ratios are assumed unchanged from those in the source material, then the convergence line (isochron line) of the points in the plots of Fig. 4 should indicate the age of the source material (TATsumoto, 1966 b; TATsumoto and SNAVEly, 1969). Since $\mathrm{U} / \mathrm{Pb}$ and $\mathrm{Th} / \mathrm{Pb}$ ratios are altered by differentiation and contamination, this type of plot does not, in most cases, indicate the true age of the source. For abyssal basalts (TATsumoto, 1966 b) the observed ${ }^{238} \mathrm{U} /{ }^{204} \mathrm{~Pb}-{ }^{206} \mathrm{~Pb} /{ }^{204} \mathrm{~Pb}$ and the observed ${ }^{232} \mathrm{Th} /{ }^{204} \mathrm{~Pb}{ }^{208} \mathrm{~Pb} /{ }^{204} \mathrm{~Pb}$ in the basalt had positive correlation. The inverse parent-daughter relationships shown by the tholeiitic and alkali basalts and their geographic distribution across the Japanese arc are pertinent to the problem of magma genesis in terms of (a) crustal contamination, (b) difference in depth, and (c) ocean-floor thrusting under the Japanese Island arcs.

(a) Crustal contamination: There is some evidence that the average $\mu$ value of the crust is higher than that of the upper mantle. CHOw and PATTERson (1962a) estimated the average $\mu$ value of the crust as 11.3 from the study of leads in Quaternary oceanic sediments. PATTERSON and TATsumoto (1964) studied the K-feldspar leads obtained from beach and river sands and they proposed that the $\mu$ values of the crust increased from 9.1 (for the central regions of North America) to 9.9 (for the coastal regions) in the geological past, contrasting to the value of about 8.6 for the basalt source regions (TAтSUMото, 1966b). Galenas in the crustal environment also fit on a high $\mu$ growth curve ( $\mu=8.95 \sim 9.0$; STACEY et al., 1969; OsTIC et al., 1967). Thus, if a parent magma is contaminated with the crustal rock (total rock lead contamination), the lead in the volcanics will fit a higher $\mu$ system than an uncontaminated one. Such examples are illustrated in Fig. 3 by calc-alkali derivatives from Amagi and Omuro-yama area in this paper and also illustrated by pyroxene andesites from Yatsugatake and Ontake (Tатsuмото, 1969). These volcanics are indeed considered by geological studies (KUNO, 1950, 1962, 1968) as being produced by crustal contamination from their parent magmas. The lead in these contaminated volcanics shows high ${ }^{207} \mathrm{~Pb} /{ }^{204} \mathrm{~Pb}$ and ${ }^{208} \mathrm{~Pb} /{ }^{204} \mathrm{~Pb}$ values relative to their ${ }^{206} \mathrm{~Pb} /{ }^{204} \mathrm{~Pb}$.

If the parent magma was contaminated with the lower melting components of crustal rocks (selective mineral lead contamination) such as $\mathrm{K}$-feldspar and plagioclase (DoE, 1967; DoE et al., 1969), in which lead is nonradiogenic due to high lead content compared to uranium and thorium contents, the lead at the Japan Sea side would have lower ${ }^{206} \mathrm{~Pb} /{ }^{204} \mathrm{~Pb}$ and ${ }^{208} \mathrm{~Pb} /{ }^{204} \mathrm{~Pb}$ indicating a larger model age than those of the Pacific side because the basement rock is older on the Japan Sea side. Such a case is illustrated in Fig.5A. Since the apparent $\mu$ value of the crust may be less than 9.1 and that of the upper mantle would not be lower than 8.4 , the two primary growth curves for $\mu=9.1$ and 8.4 are drawn as the extremes. If selective nonradiogenic lead contamination occurred, the Pacific side primary basalt would be con- 


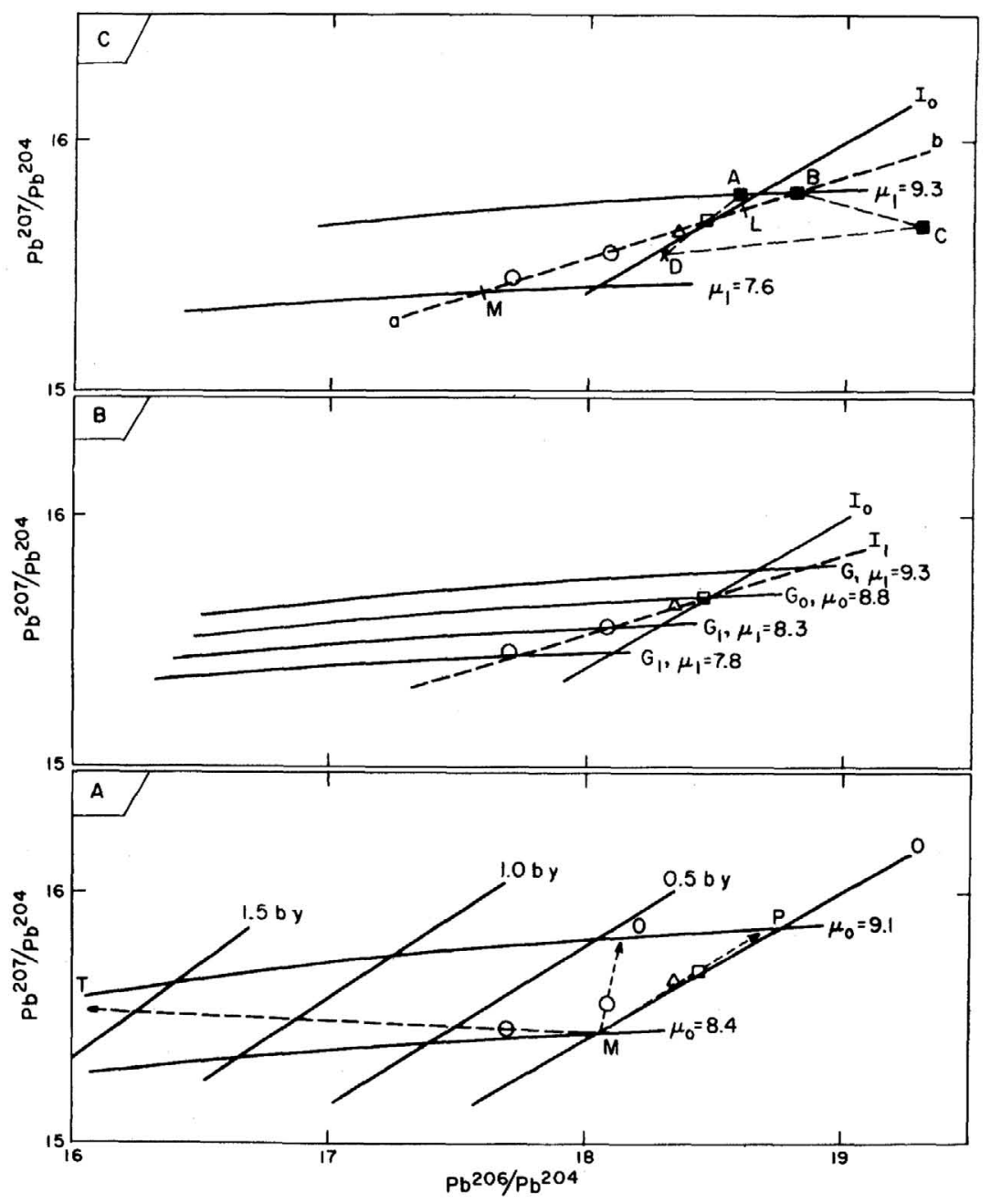

Fig.5. Models for the explanation of Japanese basalt lead. Model A illustrates selective mineral contamination. The mantle lead (M) would be contaminated with nonradiogenic mineral lead of Pacific side (P), Oki-dogo (O), and Takashima (T). Open squares, tholeiite; triangles, high alumina; circles, alkali basalt. Model B, following KUNO's hypothesis that different types of magmas form at different depths, is that an original mantle $\left(\mu_{0}=8.8\right.$ ) differentiated 3.6b.y. ago to the multi-component (zonal structure); and tholeiite was produced from the layer of $\mu_{1}=8.8$, whereas alkali basalts from Oki-dogo and Takashima were produced from $\mu_{1}=8.3$ and 7.8 systems, respectively. Model C represents a mixing model of leads between oceanic lithosphere (L) and a partial melting product $(\mathrm{M})$ of the upper mantle material of continental margin. A, leads in manganese nodule near Japan Trench; B, average value of the north Pacific sediment; $\mathrm{C}$, Easter Island lead; D, average of Pacific abyssal tholeiites. Line $a b$ is a mixing line. 
taminated by a very young crustal lead, such as P in Fig.5A, while Oki-dogo basalt and Takashima basalt would be contaminated by $400 \mathrm{~m}$.y.-old crustal lead (indicated by $\mathrm{O}$ ) and by 2 b.y.-old crustal lead (T), respectively. Because of the primary chemical character of the basalts the crustal lead should mainly be added by some special process such as volatile transfer or zone refining. These contaminating lead ages for the primary basalts of Pacific side and Oki-dogo seem to be reasonable but the age for Takashima is too old in comparison with the distribution of orogenic belts of the pre-Japanese island arc stage (GoRAI, 1968) and the basement rock ages. This type of contamination may not be the case for the Japanese basalts and whole-rock lead contamination would have occurred as discussed previously for calc-alkali derivatives.

Kuno (1967) suggested the existence of plagioclase peridotite layer at the uppermost mantle based on $V p$ measurements by Matuzawa (1959) for only the Japan Sea side of the northeast Honshu. He attributed the high heat-flow values of the area (UYEDA and HORAI, 1964) to the presence of the plagioclase peridotite layer. He also assumed the existence of the plagioclase peridotite layer for the Japan Sea side of the central Honshu. The similarity in $P$ velocity in the uppermost mantle between northeast and central Japan of Japan Sea side (MURAUCHI et al., 1967, cited from RikitaKe et al., 1968) supports Kuno's view. If processes such as "Partial zone melting" (KUSHIRO, 1968) are effective up to the uppermost mantle, the variation in the lead isotope ratios in Japanese primary basalts might be accounted for by the difference in the mineral composition of the uppermost mantle. At present, we cannot discuss more details on contamination from the uppermost mantle because of lack of precise information on the uppermost mantle of this area.

(b) Magma generation at different depth: As reported in a previous paper (TATSUMOTo, 1966a), tholeiites of the Pacific side of Japan tend to be more radiogenic in ${ }^{206} \mathrm{~Pb}$ than the alkali basalts of the Japan Sea side. This result was interpreted to indicate that the crust-mantle differentiation began in Precambrian time and the resultant inhomogeneities in the mantle have persisted since then. The present results and KURASAWA's (1968) clearly show that the apparent $\mu$ values required to explain the lead isotopic compositions decrease significantly from the Pacific side to the Japan Sea side (Fig.3). The secondary isochron that fits these primary basalts is $3.6 \pm 0.1 \mathrm{~b} . \mathrm{y}$. and it may indicate the early differentiation stage for the upper mantle of this area. The secondary isochron may not be exact because of a rather complicated orogenic history of the island arc but it is significant that lead studies of volcanic rocks indicate a long differentiation history for the upper mantle in this area. It is interesting that this figure coincides with some other figures of the oldest events on the earth. PatTERSON and TATSUMOTo (1964) suggested a 3.5 b.y. age for the onset time of the North American continental evolution and CATANZARo (1963) reported the oldest zircon age from North America as 3.55b.y. The 3.6b.y. isochron would require that an original mantle material with a $\mu_{0}$ (original $\mu$ value) of 8.8 differentiated in zones 
with different $\mu_{1}$ (secondary $\mu$ ) values. The secondary $\mu$ would be $8.8,8.3$, and 7.8 for the source materials of O-shima tholeiite, Oki-dogo alkali basalt, and Takashima alkali basalt, respectively (Fig.5B). Using these $\mu_{1}$ 's and the $3.6 \mathrm{~b} . \mathrm{y}$. secondary isochrons, the $\kappa_{1}$ 's (secondary $\kappa$ ) are calculated as 4.29 and 4.22 for the alkali basalts from Oki-dogo and Taka-shima respectively, and 4.12 for the O-shima tholeiite starting from a $\mu$ of 4.12. The lead of Oki-dogo basalt is enriched in ${ }^{208} \mathrm{~Pb}$ (Fig.3) and deviates somewhat from a trend from O-shima to Taka-shima. This may be due to the complexity of the island arcs, as discussed later.

As discussed in the previous paper (ТАтsumoto, 1966a), the general trend in the isotopic composition of lead - - decreasing radiogenic character from the Pacific side to the Japan Sea side - - seems most consistent with Kuno's hypothesis of depth control of magma generation. If chemical differentiation of the mantle in the geologic past had resulted in an upward enrichment of uranium and thorium relative to lead, the observed trend of lead-isotopic compositions in the Japanese basalts requires that alkali basalt is derived from a deeper part in the upper mantle than the tholeiites and highalumina basalts. HEDGE and KNIGHT (1969) by their comparison of U and K, support the hypothesis that $U$ is enriched upward in the upper mantle.

Kuno (1959) found distinct petrological provinces of the three basalt magma types in Quaternary volcanoes of the Japanese Islands (Fig.1). From the agreement between the distribution pattern of the three basalt magma types and the average depths of the deep-earthquake foci, and from other petrological reasoning (Kuno et al., 1957), Kuno $(1959,1960)$ postulated that tholeiite, high-alumina basalt, and alkali olivine basalt magmas are generated at earthquake foci of successively greater depths: tholeiitic magma at $100-150 \mathrm{~km}$ and magmas for high-alumina basalt and alkali olivine basalt at about $200 \mathrm{~km}$ and $400 \mathrm{~km}$, respectively. KUNo (1967) himself pointed out that the inferred depth of magma generation on Oki-dogo $(\sim 400 \mathrm{~km})$ appears to be too great compared to the results of high-pressure laboratory experiments. However, the Japanese Islands consist of several arcs (see for example Fig. 1 of MiYASHIRo, 1967, and Fig. 1 of Sugimura, 1968), and southwest Honshu should be considered separately from northeast Honshu as shown by SugimuRA (1968). Considering these areas separately the features of the volcanics, gravity anomalies, and heat flow anomalies are in agreement. The depth of seismic zone for Oki-dogo (Fig.1) which may indicate the magma forming zone is estimated as about $250 \mathrm{~km}$. The estimate appears to be consistent with the result of KANAMORI (1968) obtained from arrival time difference of $P$ wave and amplitude ratio of $P c P$ to $P$ from the longshot underground explosion. He suggests that the upper mantle in the top $250 \mathrm{~km}$ of the Japan Sea side consists of about 2 percent melt.

However, this explanation for the difference of isotopic composition in the basalts across the Japan Islands appears to differ from Kuno's hypothesis on one basaic point. Kuno $(1967$, p. 108) argued, in a reply to Yoder and Tilley $(1962$, p. 520), that 
he never assumed chemical heterogeneity of the mantle in a horizontal direction across the continental margins or in a vertical direction. Of course, a homogeneous upper mantle in terms of major chemical and mineral composition and a heterogeneous distribution of trace elements such as $\mathrm{K}, \mathrm{Pb}, \mathrm{U}$, and Th may be possible. However, in recent studies on the trace elements in probable upper mantle mineral assemblages, GAST (1968) and GRIFFIN and MURTHY (1968) suggest the importance of the accessory minerals such as phlogopite for the generation of different types of basalt magma and also the degree of partial melting of a simple mantle material (garnet peridotite) at different pressures. Thus, we prefer a heterogeneous or a laminated (zonal structure) mantle model under Japan to explain the lead isotopic variations obtained in this study. A recent geophysical study by PRESS (1968) also supports a heterogeneous mantle. Press (1968) suggests that during partial melting of a pyrolitic mantle some magma is extruded as lava but some may also remain in the upper mantle as eclogitic intrusions. If a larger amount of magma has been intruded in the upper mantle of the Japan Sea side than in the Pacific side, the high heat flow of the Japan Sea side (UYEDA and HōRAI, 1964) would probably be explained.

We observed an inverse correlation between the radiogenic character of lead and $\mathrm{U} / \mathrm{Pb}$ and $\mathrm{Th} / \mathrm{Pb}$ ratios, as shown in Fig.4. If $\mathrm{U}$ and $\mathrm{Th}$ are concentrated toward the upper part of the upper mantle, there must be some feature of the magma generation process that results in lower $\mathrm{U} / \mathrm{Pb}$ and $\mathrm{Th} / \mathrm{U}$ ratios in tholeiites, and higher $\mathrm{U} / \mathrm{Pb}$ and $\mathrm{Th} / \mathrm{U}$ ratios in alkali basalts. There is some evidence that trace elements such $\mathrm{as} \mathrm{Rb}$ and $\mathrm{Sr}$ (Allsopp et al., 1969), and U, Th, Pb (TATSUMoto and Nicolaysen, unpublished) are enriched in interstitial material of eclogite. Furthermore, partitioning of the elements among the mineral phases results in different critical ratios for $\mathrm{Rb} / \mathrm{Sr}, \mathrm{U} / \mathrm{Pb}$, and $\mathrm{Th} / \mathrm{U}$. Laboratory experiments show that lead is very mobile and can easily be extracted from basalt and eclogite by heating, and that the "loosely bound" $\mathrm{Pb}$ which is extracted during initial heating is more radiogenic than the remaining lead. There may be a process in partial melting of mantle material at different pressures and temperatures that extracts $\mathrm{Pb}$ preferentially to $\mathrm{U}$ and $\mathrm{Th}$, or an isotopically nonuniform extraction of lead. Thus, a time difference in evolutionary process across the island arc could affect the isotopic character and preferential extraction of $\mathrm{Pb}, \mathrm{U}$, and $\mathrm{Th}$. If the evolutionary process on the west side is more advanced than on the east and extracts lead which is of radiogenic character preferentially to $U$ and $T h$ at an early stage, for example in the Paleozoic, the lead in Quaternary volcanics would be less radiogenic, and also $\mathrm{U} / \mathrm{Pb}$ and $\mathrm{Th} / \mathrm{Pb}$ ratios would be higher in the west than in the east. Results on eclogites from Roberts Victor Mines, South Africa, by MANTON and TATSUMOTO (unpublished), indicate that the observed ${ }^{238} \mathrm{U} /{ }^{204} \mathrm{~Pb}$ and ${ }^{232} \mathrm{Th} /{ }^{238} \mathrm{U}$ can vary from 2 to 10 and from 3 to 6 , respectively. This suggests a possibility that eclogite formation in the upper mantle in Cenozoic time can produce the observed ${ }^{238} \mathrm{U} /{ }^{204} \mathrm{~Pb}$ and ${ }^{232} \mathrm{Th} /{ }^{238} \mathrm{U}$ values for tholeiite and alkali olivine basalts with little modification of 
the isotopic composition of the lead. Therefore, to explain the inverse correlation between parent-daughter and radiogenic character of lead (Fig.4) would require a multiple differentiation for the upper mantle (TАтsumoto, 1966a). The original mantle may have differentiated approximately $3.6 \mathrm{~b}$.y. ago producing a proto-continent as discussed by PATterson and TAtsumoto (1964) and Engel (1963). This differentiated mantle (perhaps peridotite plus eclogite) further differentiated in Cenozoic time in such a way that partial melting produced eclogite or granulite facies rocks. Then the eclogite or granulite formed lava recently. O'HARA and YodER (1967) reported that garnet-peridotite begins to melt at high pressures at a temperature below that at which bimineralic eclogite begins to melt. The YODER and TILLEY study (1962), however, suggests eclogite may melt at lower pressure or, when water is present*, at a lower temperature than garnet-peridotite. Further, there is a possibility that extensive melting of eclogite at shallower depth forms tholeiite but that less partial melting of eclogite or interstitial material of the bimineralic rock at greater depth produces alkali basalt and causes accumulation of trace elements such as $\mathrm{K}, \mathrm{Rb}, \mathrm{Ba}, \mathrm{Pb}, \mathrm{U}$, and $\mathrm{Th}$.

Kuno (1967) presented a modified model on the depth relation of the three magma types based on the YODER and TILLEY hypothesis (1962). A primary magma of either olivine tholeiite or picrite basalt composition would be generated at a comparatively uniform depth, say 100 to $150 \mathrm{~km}$. A primary magma generated on the Pacific side of the Honshu arc rises up to shallower depths and undergoes fractionation at lower pressures, whereas on the Japan Sea side the primary magma stays deeper near the magma source region and undergoes fractionation under high pressures. KUNo encountered difficulty in using this model to explain why the primary magma should leave its source region immediately after its generation on the Pacific side whereas it should stay for some period on the Japan Sea side. This modified model does not seem to be compatible with the results of the present study, because fractional crystallization of an isotopically homogenized magma cannot change the isotopic composition of lead without postulating either an unreasonably great length of time for such a process, or else magma contamination.

(c) Ocean-floor thrusting under the Japanese Islands: The inverse correlation between lead isotopic character and observed $\mathrm{U} / \mathrm{Pb}$ and $\mathrm{Th} / \mathrm{Pb}$ ratios can be explained by ocean-floor thrusting hypothesis (TATSUMoTo, 1969). The hypothesis of ocean-floor spreading (HEss, 1962; DIETZ, 1961) has been strengthened by the discovery of numerous fracture zones ( $c f$. MENARD, 1964) and of magnetic anomalies ( $c f$. VINE and MATHEWS, 1963; ViNe, 1966) on the mid-oceanic ridges. The sea-floor is thought to spread away from the oceanic ridges as rigid plates and upon reaching island arcs or continental margins it is thrust under along earthquake zones(OLIVER and ISACKs, 1967; UTsU, 1967). Invoking mantle convection to island arc areas, CoATs (1962) proposed

* Eclogite may be transformed to hornblende in the presence of water. 
an underthrust of crustal material to account for the nature of the volcanic rocks of the Aleutian arc; MiYASHIRo (1967) explained the distribution of metamorphic belts in Japan; and ARMSTrong (1968) proposed a steady-state model for explanation of evolution of crustal lead and strontium isotopes.

At the axial valley of mid-oceanic ridges, abyssal tholeiite magma is produced by partial melting of mantle peridotite; and alkali basalts which are produced by a lesser degree of partial melting are extruded on the flanks of the mid-oceanic ridges (Aumento, 1967; Oxburgh and Turcotte, 1968; Gast, 1968). The abyssal tholeiite magma is extruded and intruded at various levels in the upper mantle and spreads bilaterally, forming a rigid plate several tens of kilometers thick (MoRGAN, 1968; MCKENZIE, 1967). For simplicity of the discussion. below, we tentatively assume that the lithosphere* is a rigid plate of abyssal tholeiite composition on which a thin layer of sediment is deposited. The rigid plate, together with the sediment layer, is being thrust at continental margin.

The slowly precipitated oceanic sediment contains 70 to $80 \mathrm{ppm} \mathrm{Pb} ; 0.5$ to $3 \mathrm{ppm}$ $\mathrm{U}$, and 2.5 to $15 \mathrm{ppm}$ Th; and its observed $\mu$ and observed $\boldsymbol{\kappa}$ are less than 1 and about 5 , respectively (Table 5). Abyssal tholeiite contains about $0.5 \mathrm{ppm} \mathrm{Pb}, 0.08 \mathrm{ppm} \mathrm{U}$, and $0.15 \mathrm{ppm} \mathrm{Th}$, and its observed $\mu$ and observed $\kappa$ are about 8.5 and 2, respectively. If we assume that the lithosphere consists of 1 to 2 weight percent** of oceanic sediment and the remainder, abyssal tholeiite or eclogite, then the total $\mathrm{Pb}, \mathrm{U}$, and Th concentrations in the lithosphere are 1.25 to $2 \mathrm{ppm} \mathrm{Pb}, 0.09$ to $0.1 \mathrm{ppm} \mathrm{U}$, and 0.2 to $0.25 \mathrm{ppm} \mathrm{Th}$; these concentrations are close to the observed values of Japanese tholeiite (Table 5).

The isotopic composition of lead in the north Pacific Ocean sediment (Table 6) is reported by Chow and PAtTerson (1962a)*** The lead is somewhat variable depending on the age of the source area, but, in general, it is slightly radiogenic due to a higher $\mu$ value of the crust. Near the Japan Trench lead in the oceanic sediments appears to be less radiogenic than the average (CHOW and TATsumoto, 1964). In Table 6 , the isotopic composition of lead and abyssal tholeiite from East Pacific Rise is also

* The terminology is used in the same sense as OLIVER and ISACKS (1967) used.

** In this calculation, we used lower average values for $U$ and $T h$ concentrations in sediment, considering KU's reported values (1965) were on a $\mathrm{CaCO}_{3}$ and $\mathrm{NaCl}$-free basis. If those concentrations are higher than estimated, the mixing rate of sediment should be reduced and a preferential extraction process of $\mathrm{Pb}$ to $\mathrm{U}$ and $\mathrm{Th}$ should be considered. In any case, partial melting of source material might change trace element concentrations and their abundance ratios, thus the ocean-floor thrusting model should be tested by $\mathrm{Pb}$ isotopic composition rather than the concentrations.

*** Their corrections for the $\mathrm{Pb}$ isotopic composition (CHOW and PATTERSON, 1962b) are not applied in this paper based on comparison of CIT shelf standard measurement (TATSUMOTO, 1966a). 
Table 5. Comparison of $\mathrm{Pb}, \mathrm{U}$, and $\mathrm{Th}$ concentrations in basalts, oceanic sediment, and the rigid plate

\begin{tabular}{|c|c|c|c|c|c|c|}
\hline \multirow{2}{*}{\multicolumn{2}{|c|}{ Rocks }} & $\mathrm{Pb}$ & $\mathrm{U}$ & Th & \multirow[b]{2}{*}{$\mathrm{U} / \mathrm{Pb}$} & \multirow[b]{2}{*}{$\mathrm{Th} / \mathrm{U}$} \\
\hline & & \multicolumn{3}{|c|}{ (ppm) } & & \\
\hline \multicolumn{2}{|c|}{ abyssal tholeiite $1 /$} & 0.5 & 0.08 & 0.15 & 0.16 & 1.9 \\
\hline \multicolumn{2}{|c|}{ oceanic alkali basalt $2 /$} & 2 & 1 & 4 & 0.50 & 4 \\
\hline \multicolumn{2}{|c|}{ oceanic sediment $3 /$} & 75 & 1 & 5 & 0.01 & 5 \\
\hline \multirow{3}{*}{ Japanese 4/ } & tholeiite & 1.5 & 0.1 & 0.2 & 0.06 & 2 \\
\hline & high-alumina basalt & 5 & 0.5 & 1.3 & 0.10 & 2.6 \\
\hline & alkali basalt & 3.5 & 0.7 & 3.5 & 0.20 & 5 \\
\hline \multicolumn{2}{|c|}{$\begin{array}{l}\text { abyssal tholeiite }(99 \%) \text { plus } \\
\text { oceanic sediment }(1 \%)\end{array}$} & 1.25 & 0.09 & 0.20 & 0.07 & 2.2 \\
\hline \multicolumn{2}{|c|}{$\begin{array}{l}\text { abyssal tholeiite }(98 \%) \text { plus } \\
\text { oceanic sediment }(2 \%)\end{array}$} & 2.0 & 0.10 & 0.25 & 0.05 & 2.5 \\
\hline
\end{tabular}

1/ Average of the Pacific abyssal tholeiite, TATsumoto (1966b).

2/ Average of basalts from Easter Island, TAтSUMOTо (1966b).

3/ $\mathrm{Pb}$ from ChOw and PATterson (1962) and TAtsumoto (1957); $\mathrm{U}$ and $\mathrm{Th}$ from E. D. GolDBERG (personal communication) and KU (1965).

4/ Only the primary basalts (see text).

shown. The lead isotopic composition of oceanic alkali basalt is variable and only lead from Easter Island (ТАтsumoтo, 1966b) is shown in Table 6, but the amount of alkali basalt in oceanic area is subordinate $(<1 \%)$ to abyssal tholeiite (ENGEL et al., 1965). The isotopic composition of alkali basalt lead is, therefore, not critical for the present discussion, even though the lead concentrations in alkali basalts are two to four times higher than those of abyssal tholeiites. Thus, the isotopic composition of the thrust lithosphere such as $L$ may be inside of the triangle $A B D$ in Fig. $5 \mathrm{C}$, where $A, B$, and $D$ are sediment leads near the Japan Trench and the north Pacific, and of abyssal basalt, respectively. If the oceanic sediment is $1.5 \%$ of the thrust lithosphere as estimated from the concentration balance sheet, the lead contribution from the sediment to the total lithosphere lead is about $70 \%$ because of the high lead concentration in the sediment. The position of $L$ was chosen from this base that $70 \%$ of the sediment lead (middle point of $A$ and $B$ ) mixes with $30 \%$ of the abyssal basalt lead, and $L$ is on the trend line $A B$ of the Japanese primary basalt (Fig. $5 \mathrm{C}$ ).

We propose a model that explains the lead isotopic character of the Japanese 
Table 6. Isotopic composition of lead in basalts, oceanic sediment, and the rigid plate

\begin{tabular}{|c|c|c|c|c|}
\hline & Rocks & ${ }^{206} \mathrm{~Pb} /{ }^{204} \mathrm{~Pb}$ & ${ }^{207} \mathrm{~Pb} /{ }^{204} \mathrm{~Pb}$ & ${ }^{208} \mathrm{~Pb} /{ }^{204} \mathrm{~Pb}$ \\
\hline \multicolumn{2}{|c|}{ abyssal tholeiite $1 /$} & 18.31 & 15.50 & 38.81 \\
\hline \multicolumn{2}{|c|}{ oceanic alkali basalt $2 /$} & 19.29 & 15.66 & 39.18 \\
\hline \multirow{2}{*}{\multicolumn{2}{|c|}{ oceanic sediment $\left\{\begin{array}{l}\text { average North Pacific } 3 / \\
\text { average near Japan Trench } 4\end{array}\right.$}} & 18.81 & 15.78 & 39.29 \\
\hline & & 18.57 & 15.78 & 39.05 \\
\hline \multirow{4}{*}{ Japanese } & tholeiite $5 /$ & 18.47 & 15.68 & 38.75 \\
\hline & high-alumina basalt $5 /$ & 18.38 & 15.65 & 38.64 \\
\hline & alkali olivine basalt (Oki-dōgo) 6 & 18.08 & 15.56 & 38.60 \\
\hline & trachybasalt (Takashima) 6 & 17.80 & 15.46 & 38.09 \\
\hline \multicolumn{2}{|c|}{$\begin{array}{l}\text { abyssal tholeiite }(98.5 \%) \text { plus } \\
\text { oceanic sediment }(1.5 \%)\end{array}$} & 18.59 & 15.72 & 38.85 \\
\hline
\end{tabular}

1/ Average of the Pacific abyssal tholeiite, Tatsumoto (1966b).

2/ Only from Easter Island, TATSUMoTo (1966b).

3/ Chow and Patterson (1962a).

4/ Average of three sediments, CHOW and TATsumoto (1964).

5/ Primitive ones only.

6/ KuRASAwa (1968).

basalts in terms of the ocean-floor thrusting hypothesis (Fig.6). We assume that the primary mantle of this area with a $\mu$ of 8.8 was differentiated into the crust and residual mantle about $3.6 \mathrm{~b}$.y. ago and the resultant $\mu$ values for the crust and the mantle were 9.3 and 7.6 , respectively. These $\mu$ values are somewhat arbitrary but deduced from the observed lead value of Japanese basalt. The upper mantle under the Japanese Island arcs up to $250 \mathrm{~km}$ below the surface is about $2 \%$ melt, as AKI (1968) and KANAMORI (1968) suggested from their seismological studies, and we assume that isotopic equilibrium is attained within the melt. The rigid plate being thrust under the Japanese Islands along the earthquake foci is buried and chemical equilibrium in terms of $\mathrm{Pb}, \mathrm{U}, \mathrm{Th}$ concentrations and $\mathrm{Pb}$ isotope ratios is closely approached. The initial partial melting produces andesite when the proper temperature for partial melting of the buried lithosphere is reached. With further attainment of depth tholeiitic basalt is produced. Basalts of Somma lava and central-cone lava from 

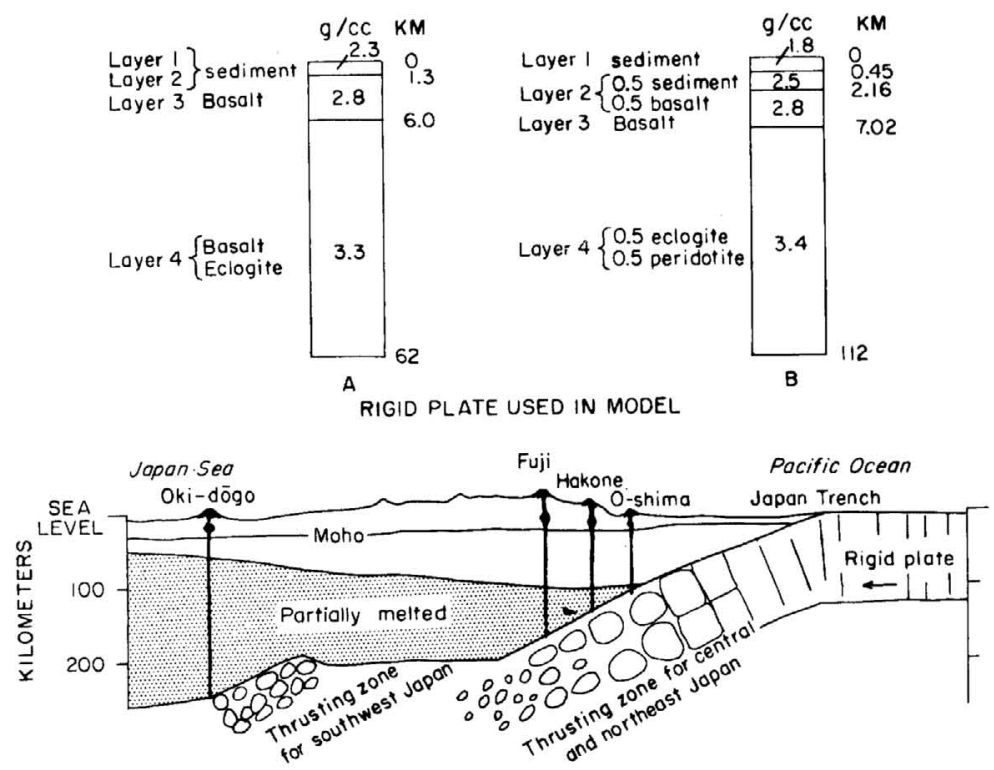

Fig.6. Illustration of the lithosphere thrusting model. A rigid plate is thrust under the Japanese Island arcs from the Pacific Ocean side. The $\mathrm{Pb}$ isotopic character may be changed by the difference in mixing ratio between oceanic lithosphere and partial melting products of the upper mantle material of continental margin. Contribution from the rigid plate decreases from the Pacific side to the Japan Sea side. The degree of partial melting of the upper mantle would be low at the east because of descending thermal plume. Thickness $(62 \mathrm{~km})$ of the rigid plate $A$ was calculated using HESS' (1962) values of specific gravity and thickness for the layers above the Moho. Thickness $(112 \mathrm{~km})$ of the rigid plate $B$ was calculated using RAITT's (1963) values for the thickness of layers 2 and 3.

O-shima contain 51 to $53 \%$ of silica and their leads are slightly radiogenic compared to the primary basalt of the island. Their leads may be most similar to lead in the thrust lithosphere. The basaltic part of lithosphere may be transformed to quartz eclogite as RINGwOoD and GREEN (1966) proposed, and with greater depths partial melting diminishes. Thus the variation in lead isotopic composition of Japanese basalts is produced by the degree of mixing of melted lithosphere plus the partially melted mantle material (continental side; such as $M$ in Fig. $5 \mathrm{C}$ ). In this model the secondary isochron line $3.6 \mathrm{~b}$.y. becomes a mixing line; however, a change in time of initial crustmantle differentiation is not necessary, because the calculated isotopic composition of lead of the lithosphere is exactly on the $3.6 \mathrm{~b} . \mathrm{y}$. isochron. If we assume that the $\mathrm{Pb}$ isotopic composition of partial melt of the upper mantle material of continental side is such as $M$ in Fig. $5 \mathrm{C}$, the primary tholeiite lead of O-shima, Hata, and Taga consists of $87 \%$ of the lithosphere lead and $13 \%$ of the mantle lead, whereas Takashima basalt lead is $10 \%$ of the lithosphere lead and $90 \%$ of the mantle lead. The mixing 
can also explain variation in the observed $\mu$ and observed $\kappa$ in basalts of the traverse. The $\mu$ and $\kappa$ values in partial melt of the upper mantle material would be significantly increased from the original mantle values and reach as high as 22 and 5.5 whereas those of the lithosphere are 2 and 2, respectively. Mixing of the two components, thus, produces variation in $\mu$ and $\kappa$ in basalt; $2-3$ and 2 for tholeiite, 5 and 2.6 for high-alumina basalt, 12 and 5 for Oki-dogo alkali basalt, and 19 and 5 for Takashima alkali basalt, respectively. The ${ }^{208} \mathrm{~Pb} /{ }^{204} \mathrm{~Pb}$ values of alkali basalts of Oki-dogo and Takashima are slightly larger than the values expected from the trend line of tholeiites and high-alumina basalts. This may be due to either the mantle heterogeneity or complexity of the island arc. If evolutionary process is more advanced in southwest Japan than in the northeast, the ${ }^{208} \mathrm{~Pb} /{ }^{204} \mathrm{~Pb}$ is increased in southwest Japan with a high $\mu$ and $\kappa$. Alternatively, another rigid plate may be thrust from south for southwest Japan, as can be imagined from the seismic depths shown in Fig. 1.

In order to mix $1.5 \%$ sediment in total lithosphere, the thickness of lithosphere which is thrusting under the island arcs is calculated as $60 \mathrm{~km}$, on the assumptions that the sediment layer (layers 1 and 2) is $1.3 \mathrm{~km}$ thick (Hess, 1962) and that the lower layer is of abyssal basalt composition. The thickness and specific gravity of the layers used in the calculation are shown in Fig.6A. However, the top layer of the lithosphere, layer 1, is oceanic sediment; layer 2 probably consists of indurated sediment and intercalated abyssal tholeiite; and layer 3 may be of basalt composition (OXBURGH and TurcotTe, 1968). We assume the remainder of the rigid plate under the $M$ discontinuity to be composed of eclogite (abyssal tholeiite composition) and peridotite. Recent studies of mantle structure (PRESS, 1968) and of Rayleigh wave propagation across the continental margin (MCGARR, 1968) suggest the existence of large amounts of eclogite. Thus, if layer 2 consists of half sediment and half basalt and layer 4 consists of half eclogite and half peridotite, the obtained thickness of the lithosphere is about $110 \mathrm{~km}$ (Fig.6B). If eclogite in layer 4 is less abundant than estimated or layer 3 is composed of partially serpentinized peridotite as Hess (1959) proposed, the thickness of the lithosphere, of course, increases. Our calculation of the approximate thickness of the lithosphere substantiates the belief that the lithosphere, which is far thicker than the depth of the $M$ discontinuity, is thrust.

RINGWOOD and GREEN (1966) proposed that dragging sediment is transformed to quartz eclogite. Andesite magma forms from the eclogite and residual eclogite sinks in the mantle as a block. TATSUmoro (1966b) suggested from a U-Pb study that the original material of the abyssal basalt is about $1 \mathrm{~b}$.y. old. It might be speculated that the eclogite blocks would circle back to the mid-oceanic ridge through the low velocity layer by mantle convection and rise up as abyssal basalt in the ridges. The estimated age of the mantle material is great compared to the size of convection cell $(2,000$ $4,000 \mathrm{~km}$ in diameter) and rate of ocean-floor spreading of $1-10 \mathrm{~cm} / \mathrm{y}(c f$. LEPICHON, 1968). However, our speculation may not be unwarranted if there is a large bottom 
layer (hot thermal boundary layer) or a longer residence time for the descended eclogite.

In conclusion, we prefer the ocean-floor thrusting hypothesis to explain $\mathrm{Pb}$ isotopic variation and some trace element concentrations in basalts across the Japanese Island arc. The presented model does not conflict, in principle, with KunO's theory of depth variation for different magma types, and it is based on his idea that basalts are formed in a deep-earthquake zone.

\section{ACKNOWLEDGEMENTS}

We are grateful to the many participants of the program of U. S. - Japan Cooperation on $\mathrm{Pb}$ and $\mathrm{Sr}$ isotope studies of basalt from the Pacific Ocean Basin, especially Professor HISASHI KUno, University of Tokyo; Dr. HaJime KuRASAWA, Geological Survey of Japan; Drs. R. G. Coleman and B. R. DoE, U. S. Geological Survey, for their cooperation in sample collection and many valuable discussions on the study. The constructive criticisms of Drs. C. E. Hedge, P. W. Lipman, and Z. E. Peterman, U. S. Geological Survey, in reviewing the manuscript are appreciated. We are also indebted to the National Science Foundation for financial support.

\section{REFERENCES}

AKI, K. (1961) Crustal structure in Japan from the phase velocity of Rayleigh Waves, Pt. 1, Use of the network of seismological stations operated by the Japan Meteorological Agency. Bull. Earthq. Res. Inst. Univ. Tokyo 39, 255-282.

AKI, K. (1968) Seismological evidences for the existence of soft thin layers in the upper mantle under Japan. J. Geophys. Res. 73, 585-594.

Allsopp, H. L., NiColaYsen, L. O. and HAHN-Weinheimer, P. (1969) Rb/K ratios and Srisotopic compositions of minerals in eclogitic and peridotitic rocks. Earth Planet. Sci. Letters 5, 231-244.

ARMSTRONG, R. L. (1968) A model for the evolution of strontium and lead isotopes in a dynamic earth. Rev. Geophys. 6, 175-199.

Aumento, F. (1967) Magmatic evolution on the Mid-Atlantic Ridge. Earth Planet., Sci. Letters 2, 225-230.

Catanzaro, E. J. (1963) Zircon ages in southwestern Minnesota. J. Geophys. Res. 68, 2045-2048.

ChOW, T. J. and PATtERson, C. C. (1962a) The occurrence and significance of lead isotopes in pelagic sediments. Geochim. Cosmochim. Acta 26, 263-308.

Chow, T. J. and PATterson, C. C. (1962b) Correction [to 1962a]. ibid. 26, 973.

CHOW, T. J. and TATSUMOTо, M. (1964) Isotopic composition of lead in the sediments near Japan Trench, in Recent research in the fields of hydrosphere, atmosphere and nuclear geochemistry, 179-183, Maruzen, Tokyo.

COATS, R. R. (1962) Magma type and crustal structure in the Aleutian arc, in The crust of the Pacific basin, Amer. Geophys. Un., Geophys. Monogr. Ser. 6, 92-109.

COOPER, J. A. and RICHARDS, J. R. (1966) Lead isotopes and volcanic magmas. Earth Planet. Sci. Letters 1, 259-269. 
DIETZ, R. S. (1961) Continent and ocean basin evolution by spreading of the sea floor. Nature $190,854-857$.

DoE, B. R. (1967) The bearing of lead isotopes on the source of granitic magma. J. Petrol. 8, $51-83$.

Doe, B. R., Tatsumoto, M., DelevauX, M. H. and Peterman, Z. E. (1967) Isotope dilution determination of five elements in G-2 (granite) with a discussion of the analysis of lead in Geological Survey research 1967. U.S. Geol. Survey Prof. Paper 575-B, B170-B177.

Doe, B. R., LiPMan, Peter W., Hedge, C. E., and Kurasawa, H. (1969) Primitive and contaminated basalts from the Southern Rocky Mountains, U.S.A., Contributions to Mineral. Petrol. (in press).

ENGEL, A. E. J. (1963) Geologic evolution of North America. Science 140, 143-152.

ENGEL, A. E. J. and ENGEL, C. G. (1964a) Composition of basalts from the Mid-Atlantic Ridge. ibid. 144, 1330-1333.

Engel, A. E. J. and Engel, C. G. (1964b) Igneous rocks of the East Pacific Rise. ibid. 146, 477-485.

ENGEL, A. E. J., ENGEL, C. G. and HAVENS, R. G. (1965) Chemical characteristics of oceanic basalts and the upper mantle. Bull. Geol. Soc. Amer. 76, 719-734.

GAST, P. W. (1968) Trace element fractionation and the origin of tholeiitic and alkaline magma types. Geochim. Cosmochim. Acta 32, 1057-1086.

GORAI, M. (1968) Some geological problems in the development of Japan and the neighboring island arcs, in The crust and upper mantle of the Pacific area, Amer. Geophys. Un. Geophys. Monogr. Ser. 12, 481-485.

GreEN, D. H. and Ringwood, A. E. (1967) The genesis of basaltic magmas. Contr. Mineral. and Petrol. 15, 103-190.

GRIFFIN, W. L. and MURTHY, V. R. (1968) Abundances of K, Rb, Sr and Ba in some ultramafic rocks and minerals. Earth Planet. Sci. Letters 4, 497-501.

HAYASE, I. (1968) The oldest rocks of Japan (abstract). Program Japan-U.S. Sci. Coop. Meet., Hakone, 28-30.

HEDGE, C. E. and KNIGHT, R. J. (1969) Lead and strontium isotopes in volcanic rocks from northern Honshu. Geochem. J. 15-24.

HESS, H. H. (1959) The AMSOC hole to the Earths mantle, Amer. Geophys. Union Trans. 40, $340-345$.

HESS, H. H. (1962) History of ocean basins, in Petrologic Studies, Geol. Soc. of Amer., New York, $599-620$.

KAMINUMA, K. (1964) Crustal structure in Japan from the phase velocity of Rayleigh waves, pt. 3, Rayleigh waves from the Mindanao shock of September 24, 1957. Bull. Earthq. Res. Inst. Univ. Tokyo 42, 19-38.

KaminUmA, K. and AKI, K. (1963) Crustal structure in Japan from the phase velocity of Rayleigh waves, pt. 2, Rayleigh waves from the Aleutian shock of March 9, 1957. ibid. 41, 217-241.

KANAMORI, H. (1968) Travel times to Japanese stations from longshot and their geophysical implications. ibid. 46 (in press).

$\mathrm{KU}, \mathrm{T}$. L. (1965) An evaluation of the ${ }^{234} \mathrm{U} /{ }^{238} \mathrm{U}$ method as a tool for dating pelagic sediments. J. Geophys. Res. 70, 3457-3474.

KUNO, H. (1950) Petrology of Hakone volcano and the adjacent areas, Japan. Bull. Geol. Soc. Amer. 61, 957-1014.

KunO, H. (1954) Geology and petrology of Ōmuro-yama volcano group, north Izu. J. Fac. Sci., Univ. Tokyo, sec. 2, 9, 241-265. 
KUNO, H. (1959) Origin of Cenozoic petrographic provinces of Japan and surrounding areas. Bull. Volcanol. 2d ser., 20, 37-76.

KuNO, H. (1960) High-alumina basalt. J. Petrol. 1, 121-145.

KUNO, H. (1962) Catalogue of active volcanoes of the world including solfatara fields, pt. 11, Japan, Taiwan, and Marianas, Intern. Assoc. Volcanol., Roma, Italy.

KUNO, H. (1967) Volcanological and petrological evidences regarding the nature of the upper mantle, in The Earth's mantle, Academic Press, 89-110.

KunO, H. (1968) Differentiation of basalt magmas, in Basalt: The Poldervaart treatise on rocks of basaltic composition, 623-688, Interscience Publ.

KUNO, H., YAMASAKI, K., IIDA, C. and NAGASHIMA, K. (1957) Differentiation of Hawaiian magmas. Japanese. J. Geol. Geography 28 (4), 179-218.

Kurasawa, H. (1959) Petrology and chemistry of the Amagi volcanic rocks, Izu Peninsula, Japan. Chikyu Kagaku 44, 1-88 (in Japanese).

KURASAWA, H. (1968) Isotopic composition of lead and concentrations of uranium, thorium, and lead in volcanic rocks from Dogo of the Oki Islands, Japan. Geochem. J. 2, 11-28.

KusHIRO, I. (1965) The liquidus relations in the systems forsterite- $\mathrm{CaAl}_{2} \mathrm{SiO}_{6}-$ silica and forsterite-nepheline-silica at high pressures. Carnegie Inst. Washington Yearbook, 64, 103109.

KUSHIRO, I. (1968) Compositions of magmas formed by partial zone melting of the Earth's upper mantle. J. Geophys. Res. 73, 617-634.

KUSHIRO, I. and KUNO, H. (1963) Origin of primary basalt magmas and classification of basaltic rocks. J. Petrol. 4, 75-89.

LEPICHON, X. (1968) Sea-floor spreading and continental drift. J. Geophys. Res. 73, 3661-3697.

MACDONALD, G. A. (1949) Hawaiian petrographic province. Bull. Geol. Soc. Amer. 60, 15411595.

MACDONALD, G. A. and KATSURA, T. (1961) Variations in the lava of 1959 eruption in Kilauea, Iki. Pacific Sci. 15, 358-569.

MACGREGOR, I. D. (1965) The effect of pressure on the minimum melting composition in the system $\mathrm{MgO}-\mathrm{SiO}_{2}-\mathrm{TiO}_{2}$. Carnegie Inst. Washington Yearbook 64, 135-139.

MACGREGOR, I. D. (1969) Mafic and ultramafic inclusions as indicators of the depth of origin of basaltic magmas. J. Geophys. Res. 73, 3737-3745.

MANTON, W. I. and TATSUMOTO, M. (1969) Isotopic composition of lead and strontium nodules from the Roberts Victor Mines, South Africa (abs.). Trans. Amer. Geophys. Union 50, 343.

MASUDA, A. (1964) Lead isotope composition in volcanic rocks of Japan. Geochim. Cosmochim. Acta 28, 291-303.

MATUZAWA, T. (1959) On the crustal structure in North-east Japan by explosion seismic observation. Bull. Earthq. Res. Inst. Univ. Tokyo, 37 (1), 123-154.

MCGARR, A. (1969) Amplitude variations of Rayleigh waves -- propagation across a continental margin. J. Geophys. Res, (in press).

MCKENZIE, D. P. (1967) Some remarks on heat flow and gravity anomalies. J. Geophys. Res. $72,6261-6273$.

MEnARD, H. W. (1964) Marine geology of the Pacific p.271, McGraw-Hill, New York.

MIYASHIRO, A. (1967) Orogeny, regional metamorphism, and magnetism in the Japanese islands. Medd. Dansk. Geol. Forening. Kobenhavn. 17, 390-446.

MORGAN, W. J. (1968) Rises, trenches, great faults, and crustal blocks. J. Geophys. Res. 73, 1959-1982.

MURThy, V. R. and PATterson, C. C. (1962) Primary isochron of zero age for meteorites and 
the earth. J. Geol. 67, 1161-1167.

O'HARA, M. J. and YODER, H. S., JR. (1967) Formation and fractionation of basic magmas at high pressures. Scott. J. Geol. 3 (1), 67-117.

OLIVER, J. and ISACKS, B. (1967) Deep earthquake zones, anomalous structures in the upper mantle, and the lithosphere. J. Geophys. Res. 72, 4259-4275.

OSTIC, R. G., RusSEll, R. D. and STANTON, R. L. (1967) Additional measurements of the isotopic composition of lead from stratiform deposits. Canadian J. Earth Sci. 4, 245-269.

OXBuRGH, E. R. and TuRCotTE, D. L. (1968) Mid-oceanic ridges and geotherm distribution during mantle convection. J. Geophys. Res. 73, 2643-2661.

PATtERSON, C. C. and TATSUmoto, M. (1964) The significance of lead isotopes in detrital feldspar with respect to chemical differentiation within the Earth's mantle. Geochim. Cosmochim. Acta 28, 1-22.

Powers, H. A. (1935) Differentiation of Hawaiian lavas: Amer. J. Sci., Ser. 5, 30, 57-71.

POWERS, H. A. (1955) Composition and origin of basaltic magma of the Hawaiian Islands. Geochim. Cosmochim. Acta 7, 77-107.

PrESS, F. (1968) Earth models obtained by Monte Carlo inversion. J. Geophys. Res. 73, 52235234.

RAITT, R. W. (1963) The sea, 3, 85-102, Interscience Publ.

Rikitake, T., MiYamura, I., Tsubokawa., I., Murauchi, S., Ueda, S., Kuno, H., and GoraI, M. (1968) Geophysical and geological data in and around the Japan Arc. Canadian J. Earth Sci. 5, 1101-1118.

RINGWOOD, A. E. and GREEN, D. H. (1966) An experimental investigation of the gabbro-eclogite transformation and some geophysical implications. Tectonophys. 3 (5), 383-427.

STACEY, J. S., DelevauX, M. H. and UlRyCh, T. J. (1969) Some triple filament lead isotope ratio measurements and an absolute growth curve for single stage leads. Earth Planet. Sci. Letters (in press).

SUGIMURA, A. (1968) Spatial relations of basaltic magmas in island arcs, in Basalts: The Poldervaart treatise on rocks of basaltic composition, 2, 537-572, Interscience Publ.

TAтsumoto, M. (1957) Chemical investigations of deep-sea deposits, 23. Tin and lead in sea sediments. J. Chem. Soc. Japan 78, 42-48 (in Japanese).

TAtsumoto, M. (1966a) Isotopic composition of lead in volcanic rocks from Hawaii, Iwo-Jima, and Japan. J. Geophys. Res. 71, 1721-1733.

TAtsumoto, M. (1966b) Genetic relations of oceanic basalts as indicated by lead isotopes. Science 153, 1094-1101.

TATSUMOTO, M. (1969) Lead isotopes in volcanic rocks and possible ocean floor thrusting beneath island arcs (in preparation).

TATSUMOTO, M. and KNIGHT, R. J. (1968) Isotopic composition of lead in volcanic rocks from Hawaii, in Abstracts for 1966. Geol. Soc. Amer. Spec. Paper 101, 218-219.

TATSUmoto, M. and NicolaySEN, L. O. (1969) Distribution of lead, uranium, and thorium in eclogite inclusions in kimberlite (abs.). Trans. Amer. Geophys. Union 50, 342.

TATSumoto, M. and SNAVEly, P. D., JR. (1969) Isotopic composition of lead in rocks of the Coast Range, Oregon and Washington. J. Geophys. Res. 74, 1087-1100.

Tilton, G. R., Patterson, C. C., Brown, H. S., Inghram, M. G., Hayden, R., JR., Hess, D. C. and LARSEN, E. S., JR., (1955) Isotopic composition and distribution of lead, uranium, and thorium in a Precambrian granite. Bull. Geol. Soc. Amer. 66, 1131-1148.

TSUYA, H. (1937) On the volcanism of the Huzi volcanic zone, with special reference to the geology and petrology of Idu and the Southern Islands. Bull. Earthq. Res. Inst. Univ. Tokyo 
$15,215-257$.

Ueno, N., Ozima, M., KUNO, H. and ShimizU, N. (1968) Rb-Sr and K-Ar isotopic investigations of granodiorites and associated metamorphic rocks from the Ryoke-Abukuma metamorphic belt. Program Japan-U. S. Sci. Coop. Meet., Hakone, 31-37.

UTSU, T. (1967) Anomalies in seismic wave velocity and attenuation associated with a deep earthquake zone (1). J. Fac. Sci. Hokkaido Univ. Japan, Ser. 7, 3, 1-25.

UYEDA, S. and HORAI, K. (1964) Terrestrial heat flow in Japan. J. Geophys. Res. 69, 2121 -2142 .

VINE, F. J. (1966) Spreading of the ocean floor: New evidence. Science 154, 1405-1415.

VINE, F. J. and MATTHEWS, D. H. (1963) Magnetic anomalies over ocean ridges. Nature 199, 947-949.

Yoder, H. S., JR., and TILlEY, C. E. (1962) Origin of basalt magmas: An experimental study of natural and synthetic rock systems. J. Petrol. 3, 342-532. 